\title{
NOVEL ELECTRIC FIELD EXPOSURE CONTROL METHODS FOR MULTI-STORY BUILDINGS INSTALLED IN VICINITY OF HIGH-VOLTAGE APPARATUS USING FEM
}

\author{
${ }^{1}$ Asaad Shemshadi and ${ }^{2}$ Pourya Khorampour \\ ${ }^{1{ }^{2}}$ Department of Electrical Engineering, Arak University of Technology, Arak, Iran, \\ Tel: +988633400615, e-mail: shemshadi@arakut.ac.ir, poriyakhp@gmail.com,
}

Received Date: August 10, 2020; Revised Date: March 5, 2021; Acceptance Date: September 27, 2021

\begin{abstract}
Facilities and buildings installed nearby high-voltage equipment and electric field exposure is always a serious threat to the health of organisms and can have a significant impact on the functioning of sensitive and vital organs such as the heart and brain. Therefore, it is necessary to study the electromagnetic field value in these areas to control the intensity and restrict the induced value regarding to international recommendations. In this paper, the effects of $230 \mathrm{KV}$ transmission line electric fields on the environment are examined by proper FEM software. The model under consideration in this project is a four-story building adjacent to the $230 \mathrm{KV}$ transmission line. At first, the distance between the building and high-voltage transmission lines and its relationship to the intensity of the electric field is examined, and then the intensity of the electric field is compared to the standards of the International Commission on Non-Ionizing Radiation Protection (ICNIRP). To continue, in places where the electric field exceeds the standard level value, solutions to reduce the intensity of the electric field to the tolerable value have been proposed.The first solution is to use a metal shield around the building as a Faraday cage, which weakens the potential for electric field value by creating an enclosed surface, the reduction rate is $4700 \%$,both complete cage shape and incomplete cage shapes are considered in this study which reduces the exposure value to $62.5 \%$ of its initial value. The second approach to reducing the electric field is to use protective conductor paints against electromagnetic fields. In the following study, the effect of using trees as a barrier against electromagnetic radiation will be examined. Finally, the three proposed solutions are compared in terms of environmental constraints, economic justification, and the reduction in electric field value.
\end{abstract}

Keywords: Electric field exposure, Finite element method, High voltage apparatus, Multi-story buildings, Occupational health

\section{Introduction}

Today, with the development of new technologies and the development of industries, electrical energy has become an integral part of the life of modern societies, and the irreplaceable role of electrical equipment in this development is undeniable. Electricity generation, transmission and distribution are carried out at high voltages, so the intensity of electromagnetic fields around high-voltage installations is one of the risks that affect human life. With the increasing population and expansion of urban fabric, some high voltage equipment, such as high voltage transmission lines due to mismanagement in construction or implementation of the power supply network, has entered the residential area and 
unfortunately has become part of the urban structure that is not noticed. Complications from radiation can cause irreparable damage to the health of the inhabitants of these areas. Therefore, it is necessary to study the intensity of the electric field in these areas and to provide protection strategies to protect it from its damages. One hundred years ago, equipment with very low-frequency electromagnetic fields, especially at frequencies of 50 to $60 \mathrm{~Hz}$, was used in power transmission lines. Today, with the development of the electricity industry, the importance of these fields has increased compared to natural fields. Because all living organs have an internal electrical current and electric field that plays a key role in the complex mechanisms of physiological control, neural activity and growth, tissue development and repair, the effects of these fields need to be looked at more closely be investigated. Figure 1 shows the interaction of internal and external fields in the human body [1].

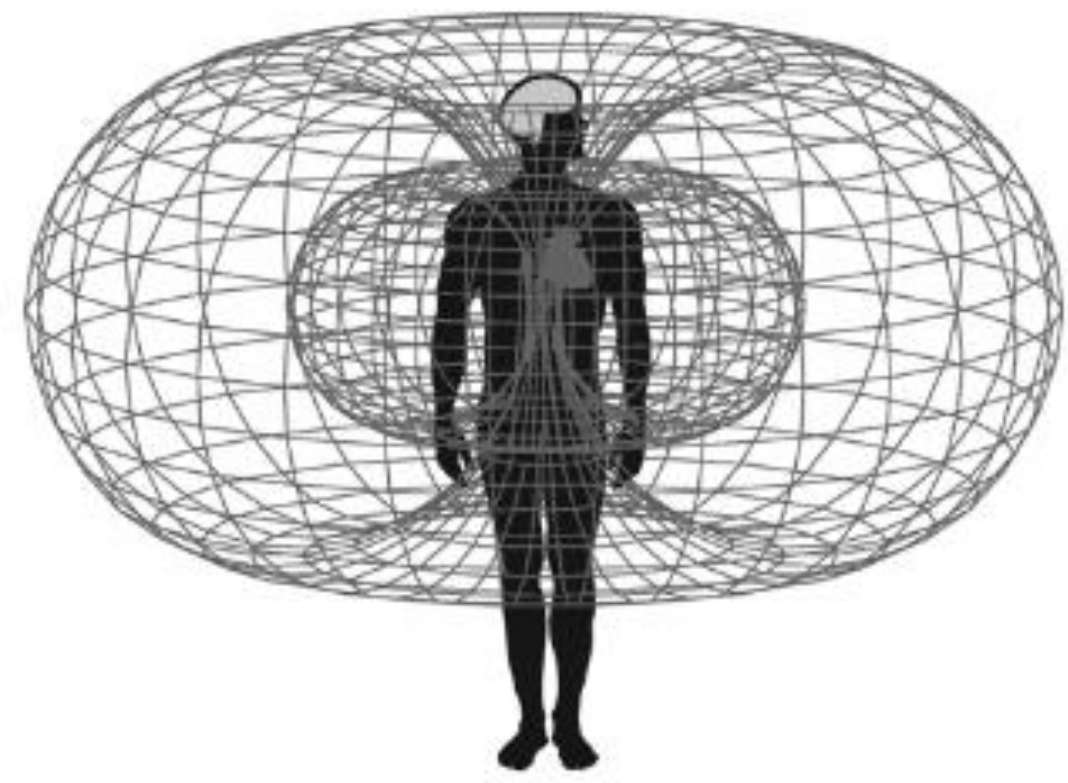

Figure 1. Interaction of internal and external fields of the human body

Due to the importance of low-frequency electromagnetic waves (Extremely Low Frequency), the mechanism of their effect on biological tissues has already been discussed. In the frequency range of less than $200 \mathrm{~Hz}$, the magnetic field is an effective factor in creating biological effects. In this frequency range, electric and magnetic fields interfere with biochemical connections in the intercellular area, indicating that the influence of an external electromagnetic field can greatly impede the establishment of biochemical communication. Accordingly, the mechanism of alternating electric and magnetic fields leads to serious health problems. The risks associated with these fields are known and undeniable, so long-term exposure to these waves is a factor in the disease. Electromagnetic waves have two components: electric field and magnetic field. The magnetic component of the electromagnetic field, unlike the electrical part of the wave, affects the biological tissues. In other words, some pathological mechanisms will be stimulated by the magnetic component and others differently by the electric component of the field. Therefore, different parts of the spectrum of electromagnetic waves have very different effects on human tissues. Figure 2 shows the induction of electric and magnetic fields in the vicinity of power transmission lines on the human body [2-5]. 


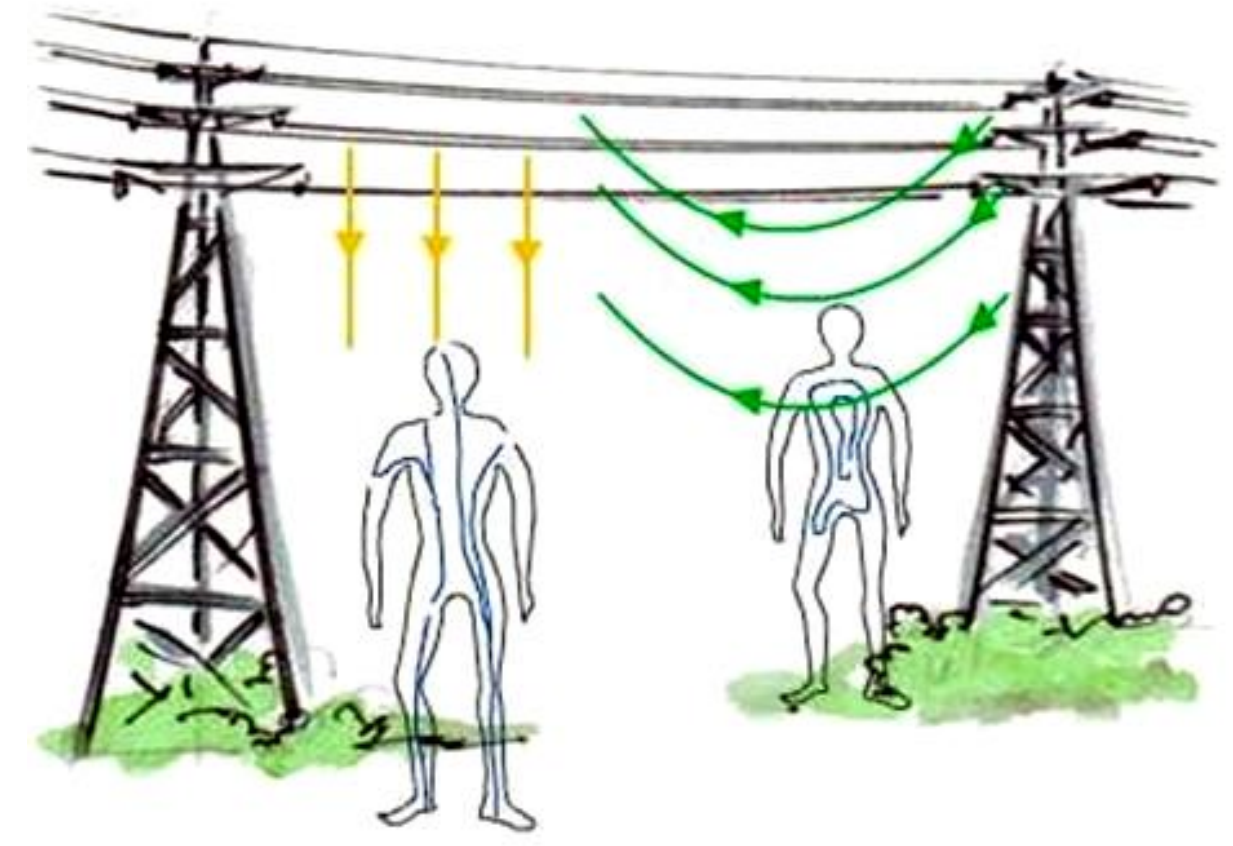

Figure 2. Electric and magnetic fields in the vicinity of Power transmission lines and affecting the human body

Advances in electromagnetic engineering technology, on the one hand, have paved the way for the advancement of medical and biological technologies and, on the other hand, have raised concerns about the effects of waves on living organisms. In the face of external fields, the size of the electric fields inside the biological systems is much lower than outside the tissues. This is due to the satisfaction of the boundary conditions caused by Maxwell's laws, which leads to an electric current in the biological system.

The human body acts as a parasitic antenna, and when it is placed near electrical sources such as power lines and other electrical devices, the electric field and thus the current induced in the body, a large part of the electric field in the body is weakened, but the field that enters It leads to flow in the body. The magnetic field also induces an electric field, resulting in a current in the conductor part of the body. Electric and magnetic fields can produce significant biological effects without breaking chemical bonds [6,7]. First, let's talk briefly about the impact of electromagnetic waves on some of the body's basic structures, including protein structure, DNA links, and some other problems and diseases caused by these waves. Radiation from electromagnetic waves can lead to changes in protein structure and thus the production of biological effects. Exposure to electromagnetic waves leads to DNA breakdown and chromosomal aberrations.

Human cancers are the result of various accumulations of genetic and epigenetic changes in a population of cells, and in fact, cancer begins with DNA damage [8,10-12]. The effect of electromagnetic waves on some organs of the body, such as the heart, brain, eyes, ears and skin, and several problems and diseases caused by these waves, will now be examined. One of the vital systems in humans is the cardiovascular system. The natural function of the heart depends on its electric current, which is very precisely coordinated and 
rhythmic. The relatively large flow of the heart creates a Gaussian magnetic field around the chest. This magnetic current of the heart itself is exposed to other magnetic currents in the environment. Any disturbance in these magnetic properties and the electrical current of the heart itself can cause disorders such as arrhythmias.

Experimental and epidemiological studies have shown that exposure to a magnetic field affects the variability of heart rate and is associated with arrhythmic risks leading to death. Many studies have shown that electromagnetic fields affect the physiology of the human central nervous system and cause morphological, electrophysiological, and chemical changes in brain structure. When microwaves are consumed, the absorbed energy is converted into heat, which increases the temperature slightly but quickly. This increase in temperature occurs in a very short time, resulting in an acoustic wave that damages the ear cells. Also, the cornea of the eye has a slow metabolism, and the eye does not have a thermal sensor, so it does not show any protective reaction against the heat process that occurs and is easily damaged. According to skin cells, they are the first cells to be exposed to electromagnetic waves. Electromagnetic waves can penetrate the nucleus of cells and damage skin cells, some of which can lead to skin cancer. Increased electromagnetic vibrations affect sperm and egg quality, and if a person is exposed to electromagnetic fields, they can result to DNA damaged and infertility [9, 10, 13]. The International Commission on the Protection of Non-Ionizing Radiation is responsible for providing relevant safety standards following human health. The commission is recognized by the World Health Organization (WHO). The ICNIRP Commission's proposed guidelines have been adopted as an appendix to national laws in many countries around the world and are used as the basis for accepted proposals and guidelines for the protection of the general public and employees $[14,15]$.

\section{Strategies Protection Against Electromagnetic Waves}

We know that when a load is placed on the conductor, it is distributed on its outer surface and the intra-field will be zero, based on which the Faraday cage is built. It will greatly prevent the penetration of waves into the building. If this metal shield can be connected to zero potential, the intensity of the reduction will be more significant, which is called the correlation in the building. We know that the conduction of the conductor in the environment can change the intensity of the field. The manufacturer claims that this paint covers 7-5 square meters per liter, which according to these specifications, its thickness has been calculated and included in the simulation. This protector is black and can be used as a coating paint.

Trees and plants also have some conductivity due to the presence of water in their tissues, and if exposed to electromagnetic waves, they may be able to reduce the intensity of radiation.

\section{Implementation and Modeling}

Comsol Multiphysics software is basically a complete set of simulations that can solve differential equations in a graphical simulation environment using finite element method. After creating the simulation environment in the software, we create the objects and structures of the problem studied in the environment. 
In this case, we need to define a large space according to Figure 3 as a free space (air) on which the infinite initial conditions (zero voltage) can be defined.

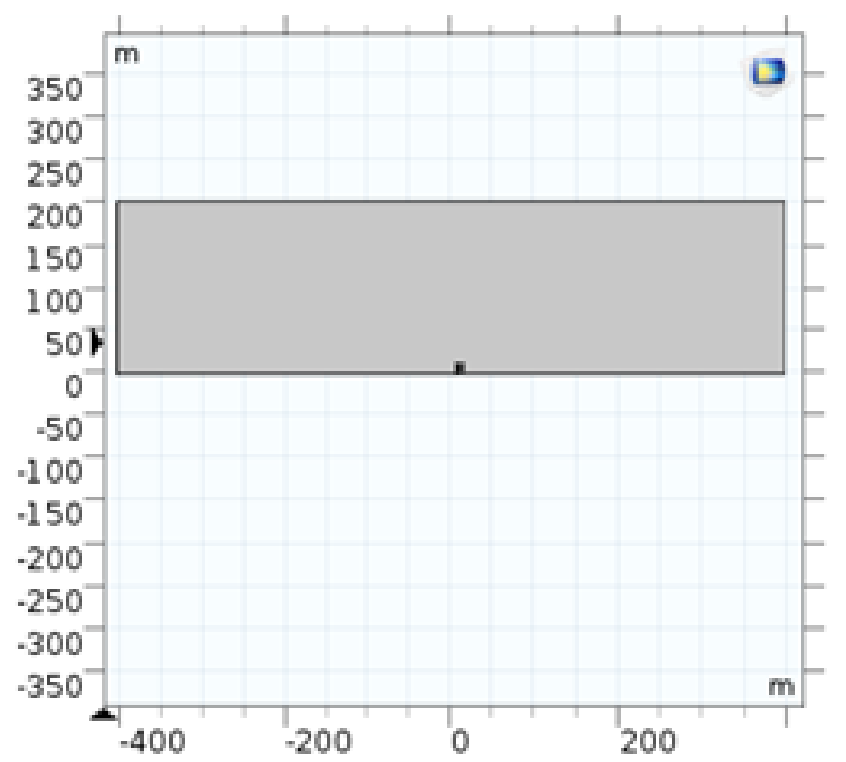

Figure 3. Create a problem model

Given that the simulation space is two-dimensional, and the transmission line of the bundle is twofold, according to Figure 4, we use two circles to simulate each phase as bundle conductors.

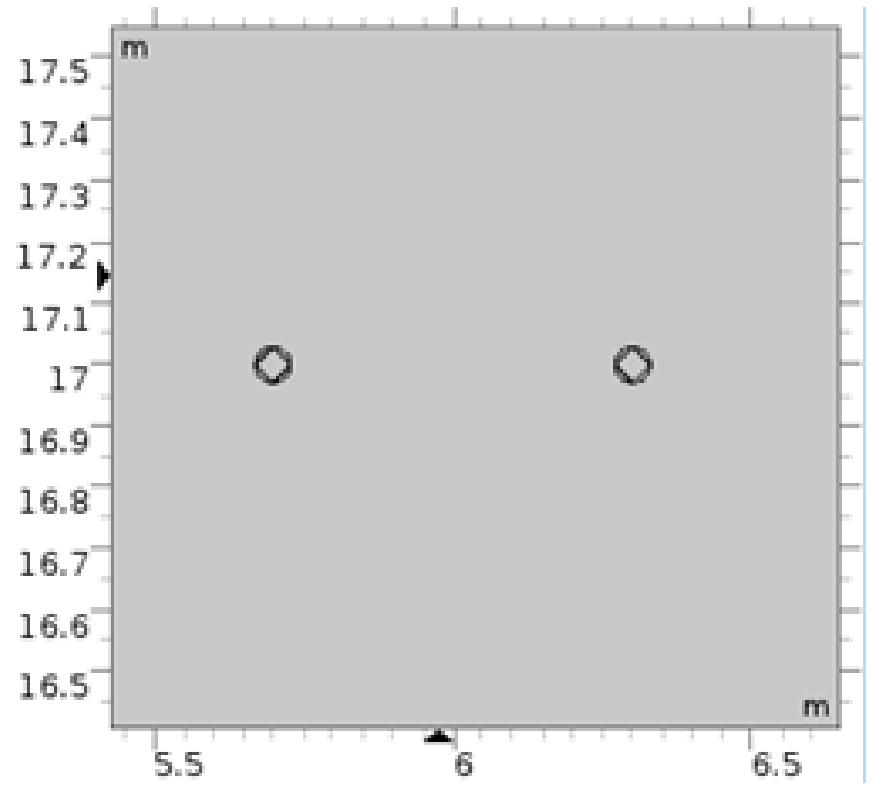

Figure 4. bundle line model 
According to Figure 5, four $2.8 * 7$ rectangles for the floors and one $12.2 * 7$ rectangle for the side walls and roof of the building were used to simulate the four-story building. The walls, ceiling and height of each floor are considered following construction standards.

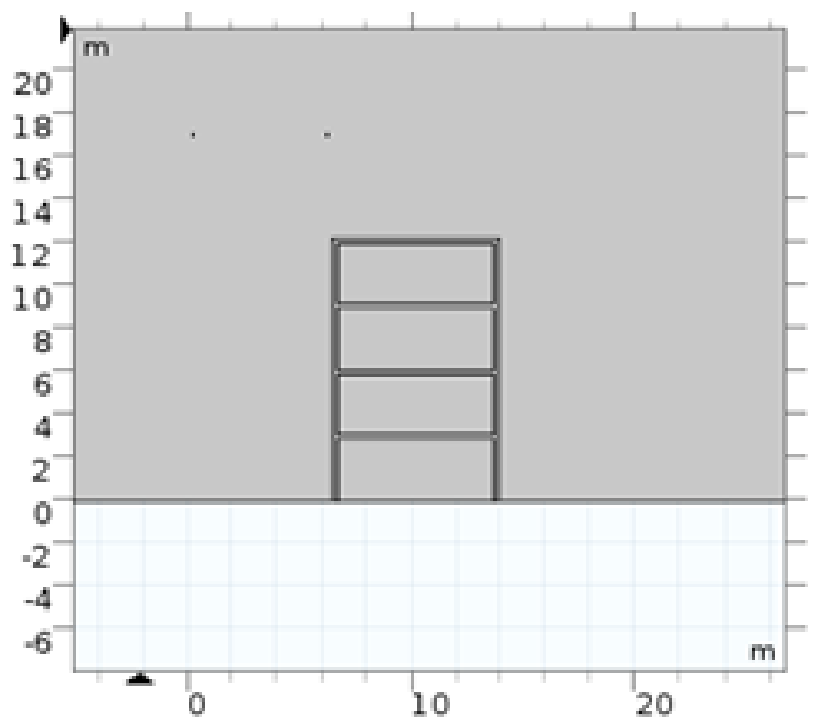

Figure 5. Problem building model

Next, the boundary conditions of the problem, including zero voltage and phase voltage, must be defined. As shown in Figure 6, a Ground and three Electric potentials are entered for this purpose.

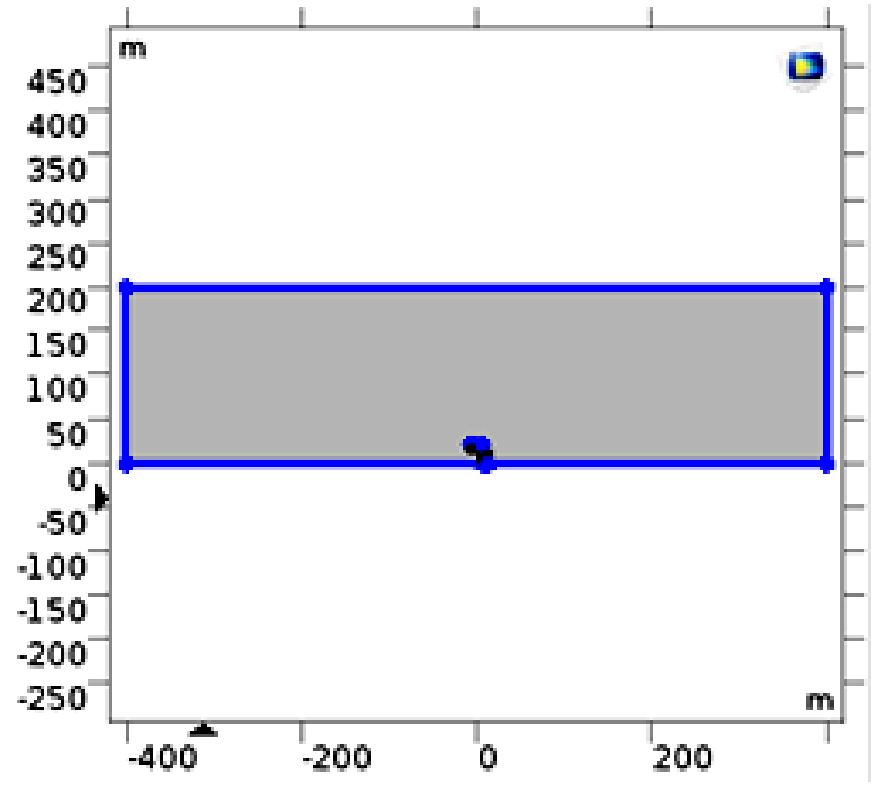

Figure 6. Determining the boundary conditions of the problem 
After determining the initial conditions, the type of mesh configuration should be determined. There are two methods of configuration: Physics-controlled mesh and Usercontrolled mesh. In the second case, the user himself has more freedom to act, which in this case, according to Figure 7, the first mode has been used with Extremely Fine accuracy.

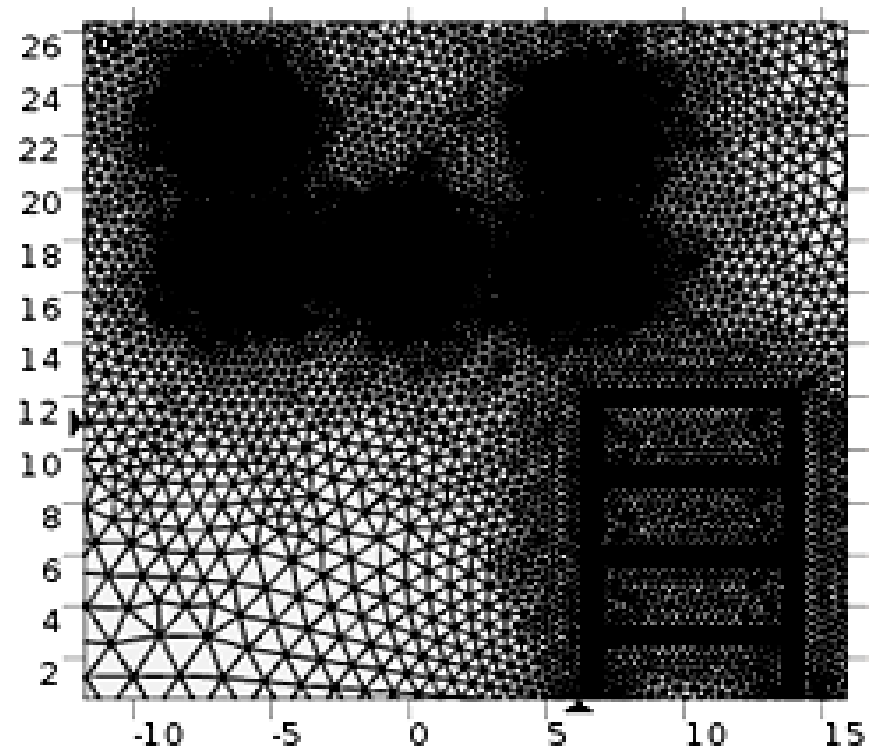

Figure 7. The meshing structure of the solving domain

In the Study section, the simulation time is set to a period of $20 \mathrm{~ms}$, with steps of 0.0005. Finally, to view the results in a specific line, cut the Line to get the chart of the field changes in that direction, cut point can also be used to view the field in a series of specific points, both of which are shown in Figures 8 and 9.

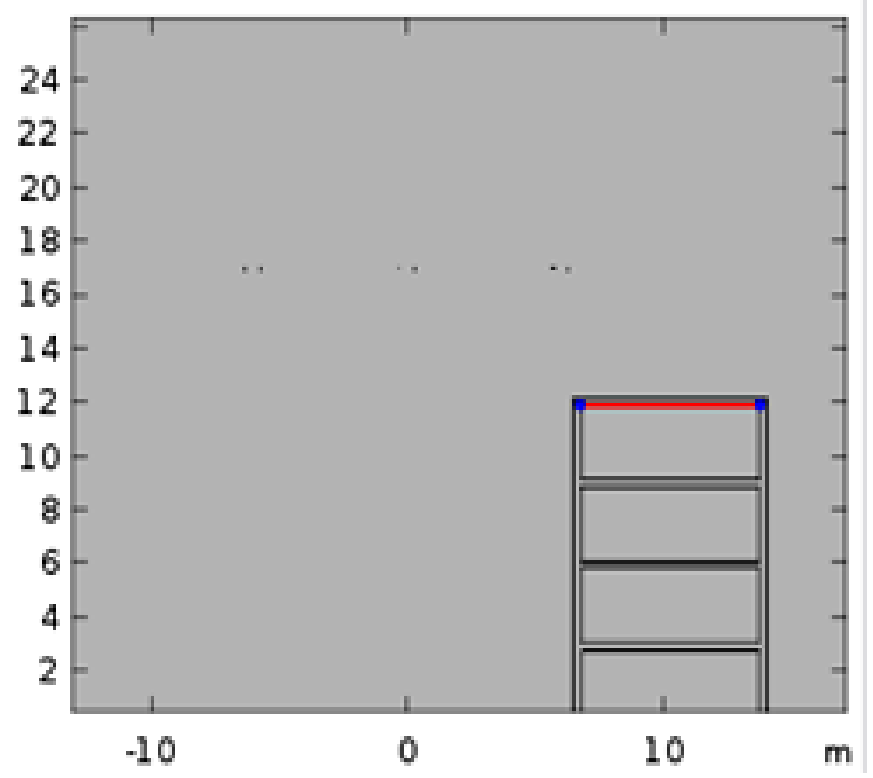

Figure 8. Definition of cut line 


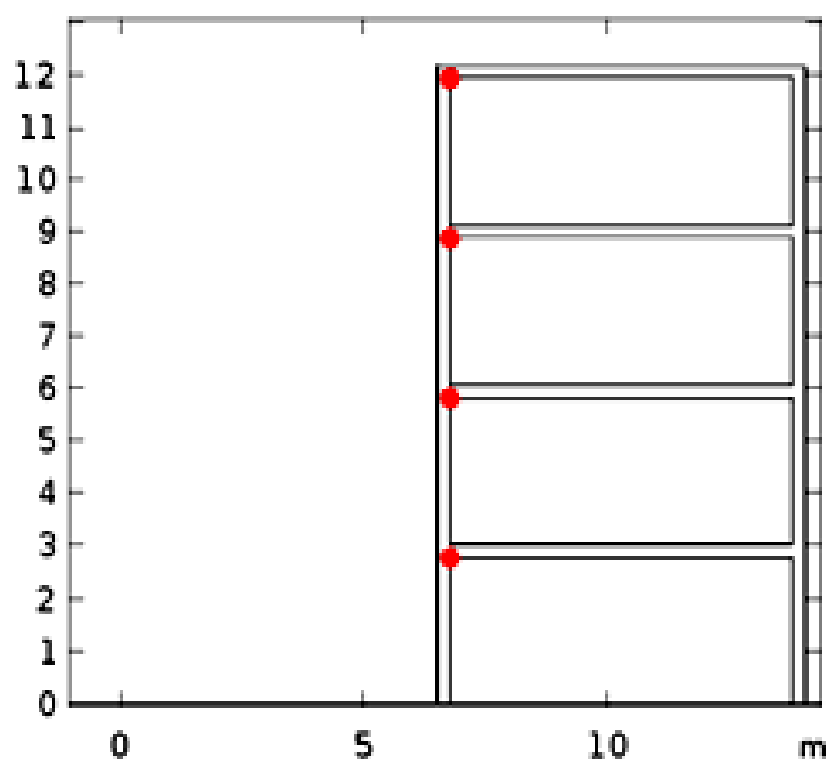

Figure 9. Definition of cut point

Domains and their electrical parameters [16] and utilized boundary conditions during simulation process are shown in Table 1 .

Table 1. The Boundary Condition, Material / Sub domain Settings and Values

\begin{tabular}{|c|c|c|c|c|}
\hline \multirow{2}{*}{$\begin{array}{c}\text { Simulation } \\
\text { Parameters }\end{array}$} & \multicolumn{2}{|c|}{ Domain } & \multicolumn{2}{|c|}{ Boundary Conditions } \\
\cline { 2 - 5 } & $\epsilon_{r}$ & $\begin{array}{c}\sigma \\
(\Omega . \mathrm{m})^{-1}\end{array}$ & \multicolumn{2}{|c|}{$\begin{array}{l}\text { Ph. A: 190.7Sin }(100 \times \pi t) \mathrm{kV} \\
\text { Ph. B: 190.7Sin }(100 \times \pi t- \\
2 \pi / 3) \mathrm{kV} \\
\text { Ph. C: } 190.7 \operatorname{Sin}(100 \times \pi t- \\
4 \pi / 3) \mathrm{kV}\end{array}$} \\
\hline Concrete & 4.5 & $5 \times 10^{-3}$ & Earth Surface & $0(\mathrm{~V})$ (terminated as ground) \\
\hline Tree & 80 & $3 \times 10^{-1}$ & Concrete Surface & Zero Charge n. $D=0$ \\
\hline $\begin{array}{c}\text { Earth Surface } \\
\text { (Dry Soil) }\end{array}$ & 2.2 & $3.3 \times 10^{-3}$ & $\begin{array}{c}\text { Tree Boundary } \\
\text { In contact with air }\end{array}$ & Zero Charge n. $D=0$ \\
\hline Metals (Fe) & $\infty$ & $1.03 \times 10^{7}$ & $\begin{array}{c}\text { Semi conductive } \\
\text { Paint Boundary in } \\
\text { contact with air }\end{array}$ & Zero Charge n. $D=0$ \\
\hline paint & 15 & $1.25 \times 10^{3}$ & \multicolumn{2}{|c|}{} \\
\hline
\end{tabular}

\section{Simulation and Study Results}

After simulating and solving the problem, a general study of the field value in the building floors from different distances of the line axis has been done and shown in Table 2. 
Table 2. The Value of Electric Field on The Floor at Different Distances from The Axis

\begin{tabular}{|c|c|c|c|c|}
\hline $\begin{array}{c}\text { Distance from } \\
\text { The Line Axis } \\
(\mathbf{m e t e r s})\end{array}$ & $\begin{array}{c}\text { First Floor } \\
\left(\frac{\boldsymbol{V}}{\boldsymbol{m}}\right)\end{array}$ & $\begin{array}{c}\text { Second } \\
\text { Floor }\left(\frac{\boldsymbol{V}}{\boldsymbol{m}}\right)\end{array}$ & $\begin{array}{c}\text { Third } \\
\text { Floor }\left(\frac{\boldsymbol{V}}{\boldsymbol{m}}\right)\end{array}$ & $\begin{array}{c}\text { Fourth } \\
\text { Floor }\left(\frac{\boldsymbol{V}}{\boldsymbol{m}}\right)\end{array}$ \\
\hline $0(\mathrm{~m})$ & 1340 & 2000 & 3370 & 6850 \\
\hline $3(\mathrm{~m})$ & 1590 & 2485 & 4150 & 8350 \\
\hline $6(\mathrm{~m})$ & 1976 & 2691 & 4050 & 6380 \\
\hline $9(\mathrm{~m})$ & 2060 & 2462 & 3205 & 3993 \\
\hline $14(\mathrm{~m})$ & 2990 & 3040 & 3080 & 3010 \\
\hline $19(\mathrm{~m})$ & 1174 & 1184 & 1180 & 1125 \\
\hline $24(\mathrm{~m})$ & 822 & 810 & 782 & 726 \\
\hline
\end{tabular}

As can be seen in Table 2, the intensity of the electric field on the fourth floor of the building in the three distances of 3.0 and 6 meters of the line axis has exceeded the allowable limit. Here are some tips to help you get the most out of your electric field.

\section{Metal Shield}

\section{Complete Cage}

The first scenario to investigate the use of universal protection is the Faraday cage. In this simulation, according to Figure 10, a complete cage with a thickness of $2 \mathrm{~mm}$ and made of iron has been used to protect the building against waves.

The results of the maximum field value in the classes and from different distances are shown in Figures 11 to 16.

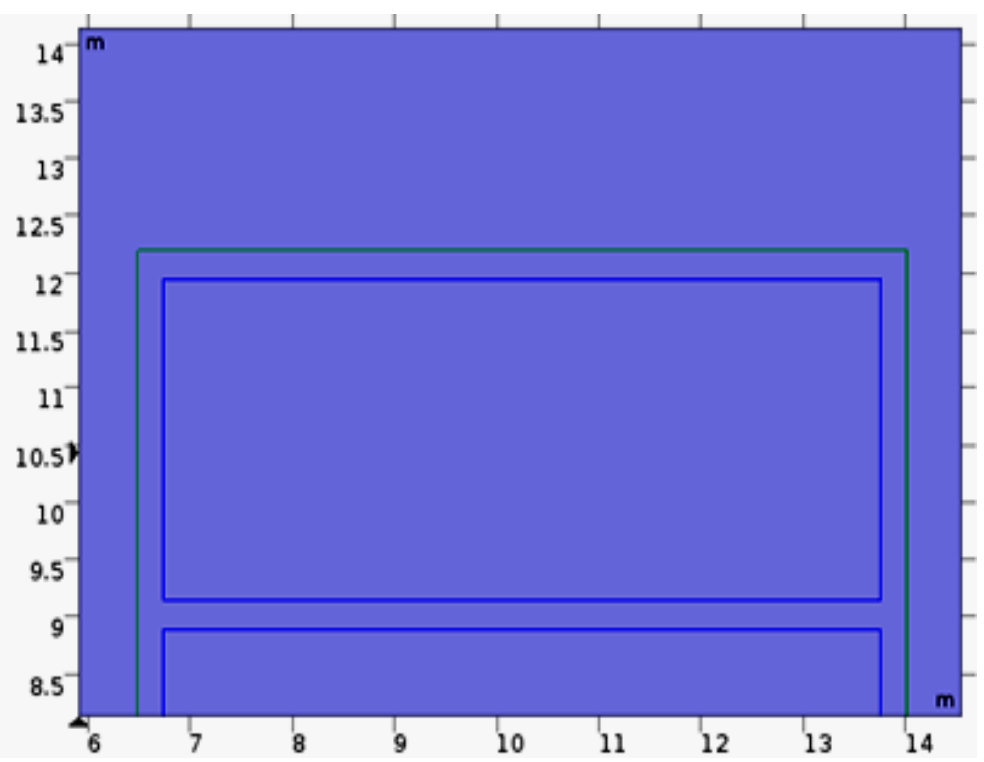

Figure 10. Complete cage model 


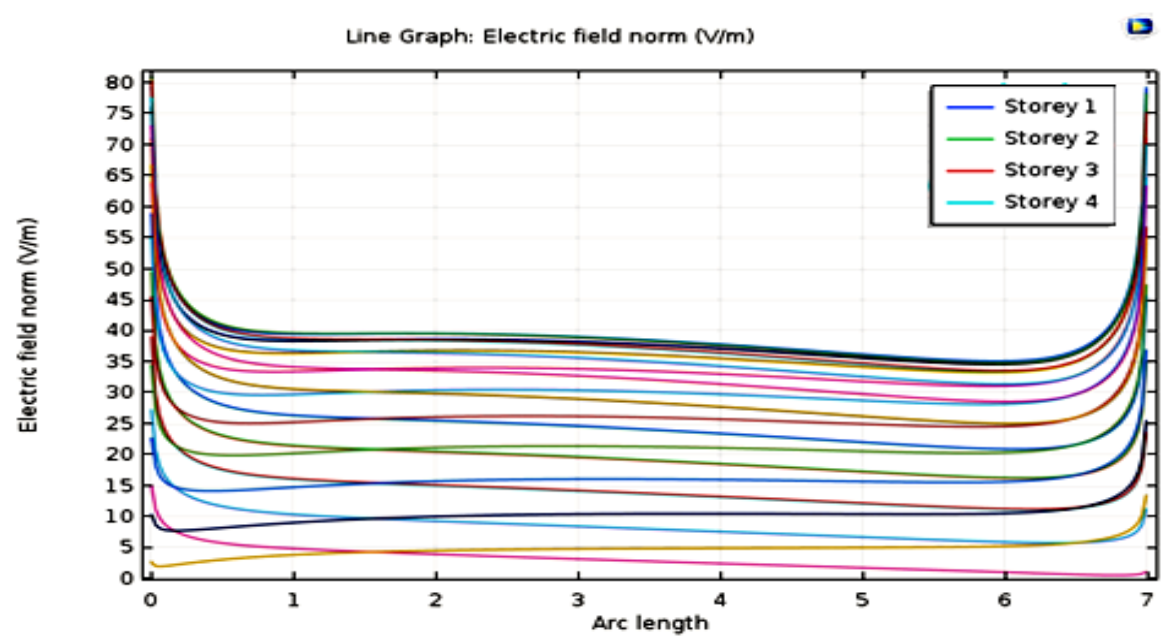

Figure 11. Maximum electric field values on the fourth floor (distance 6 meters)

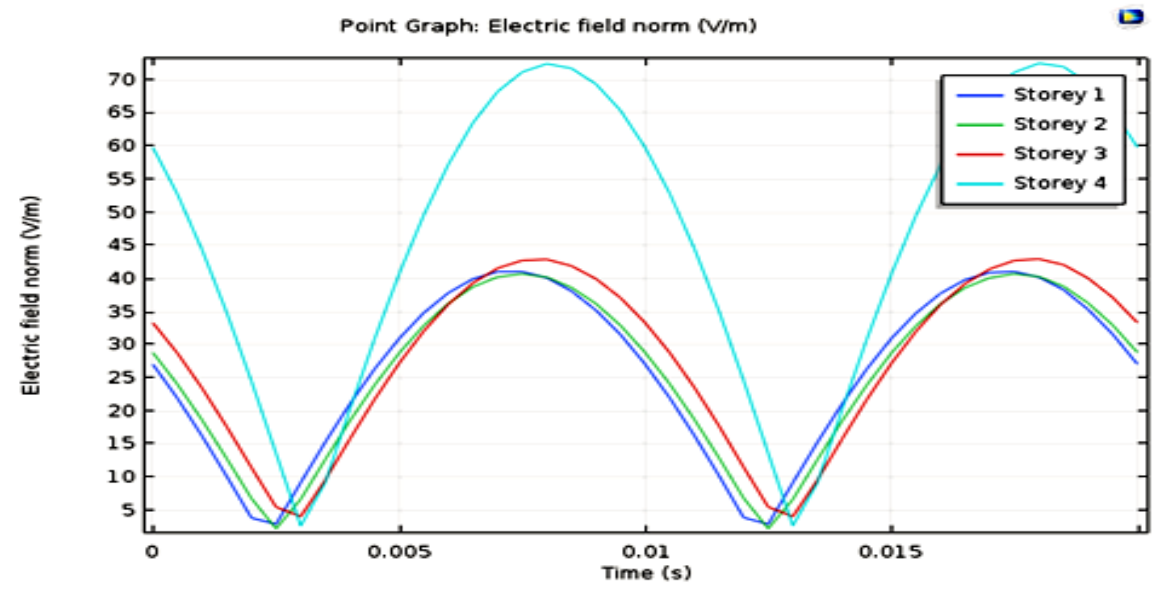

Figure 12. Maximum electric field value in different floors (distance 6 meters)

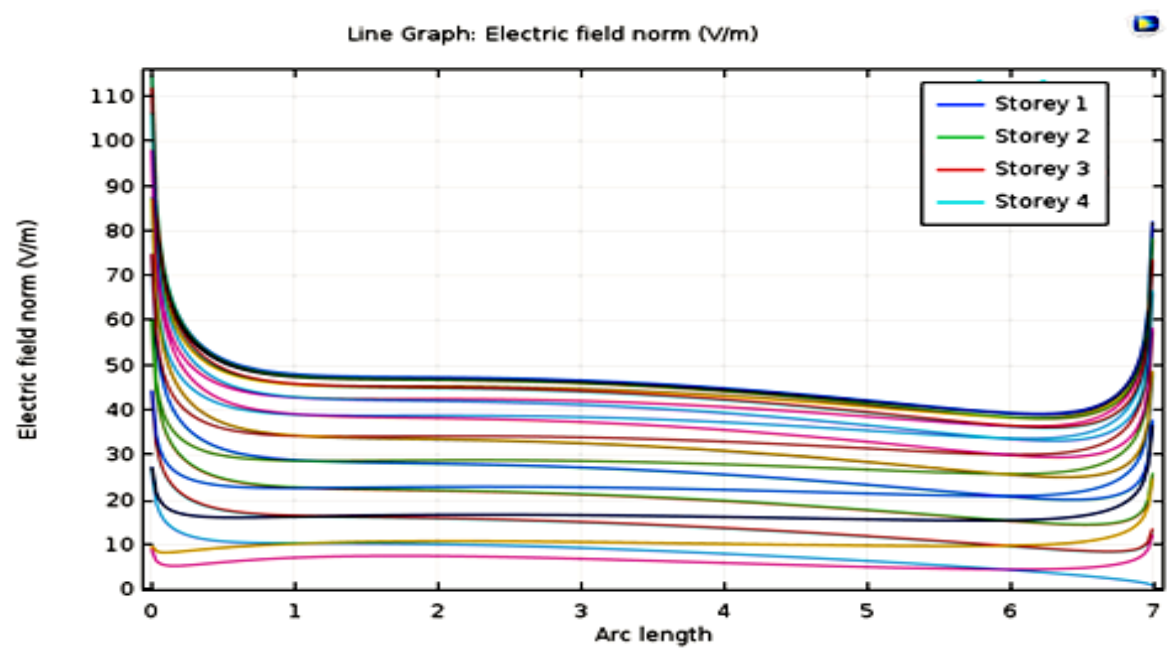

Figure 13. Maximum electric field value on the fourth floor (distance 3 meters) 


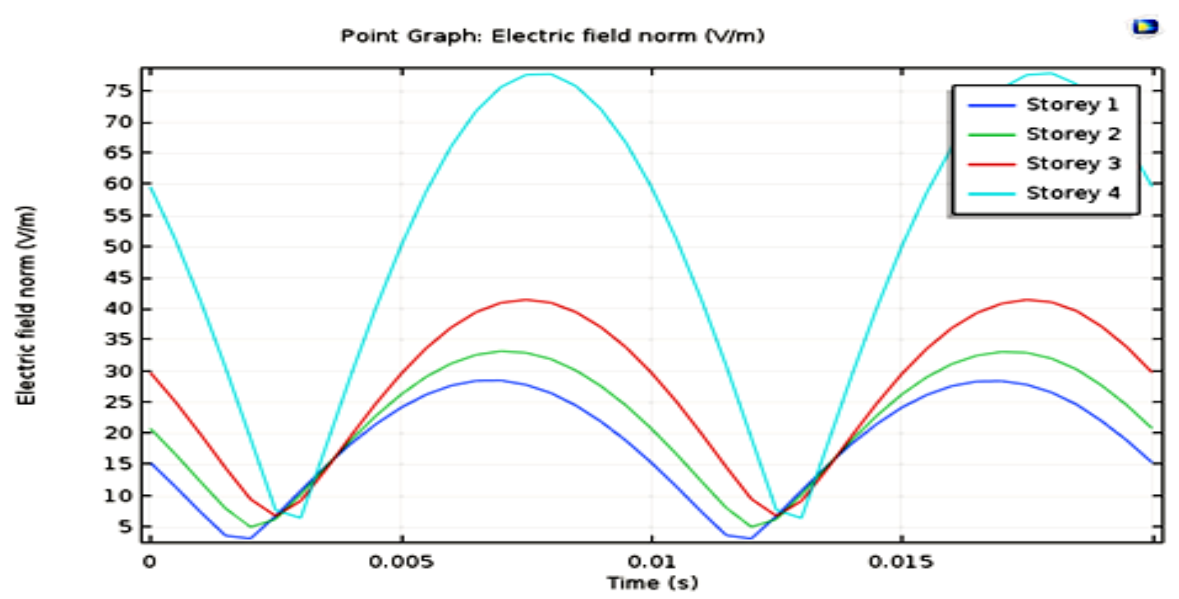

Figure 14. Maximum electric field value in different floors (distance 3 meters)

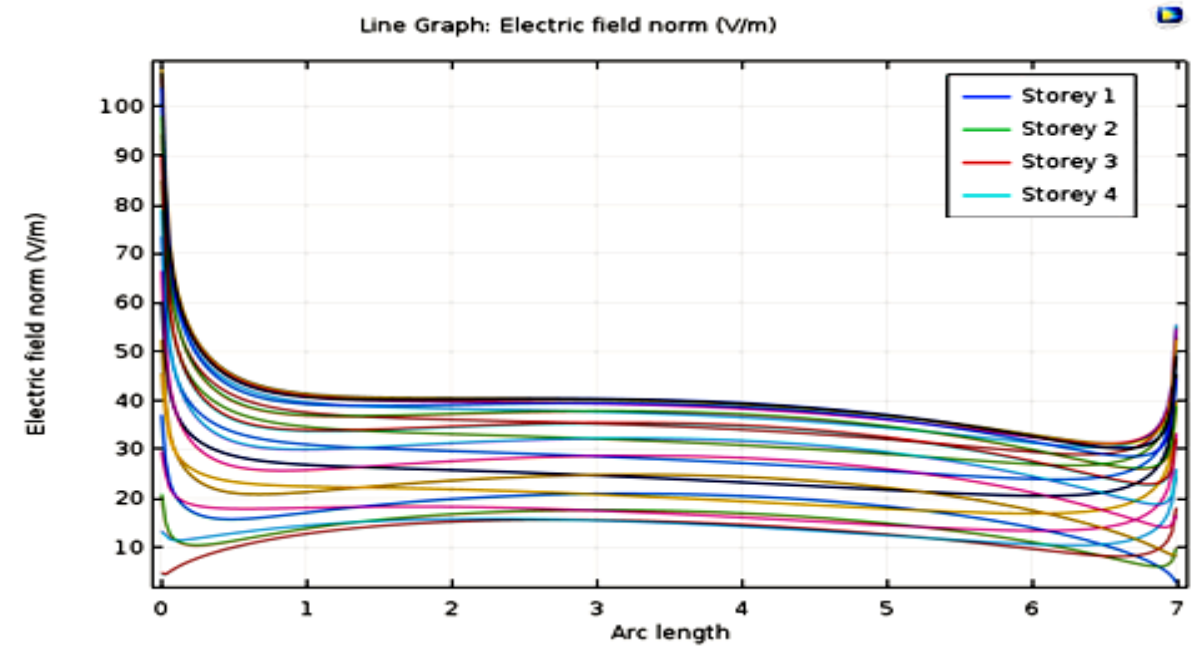

Figure 15. Maximum electric field values on the fourth floor below the line axis

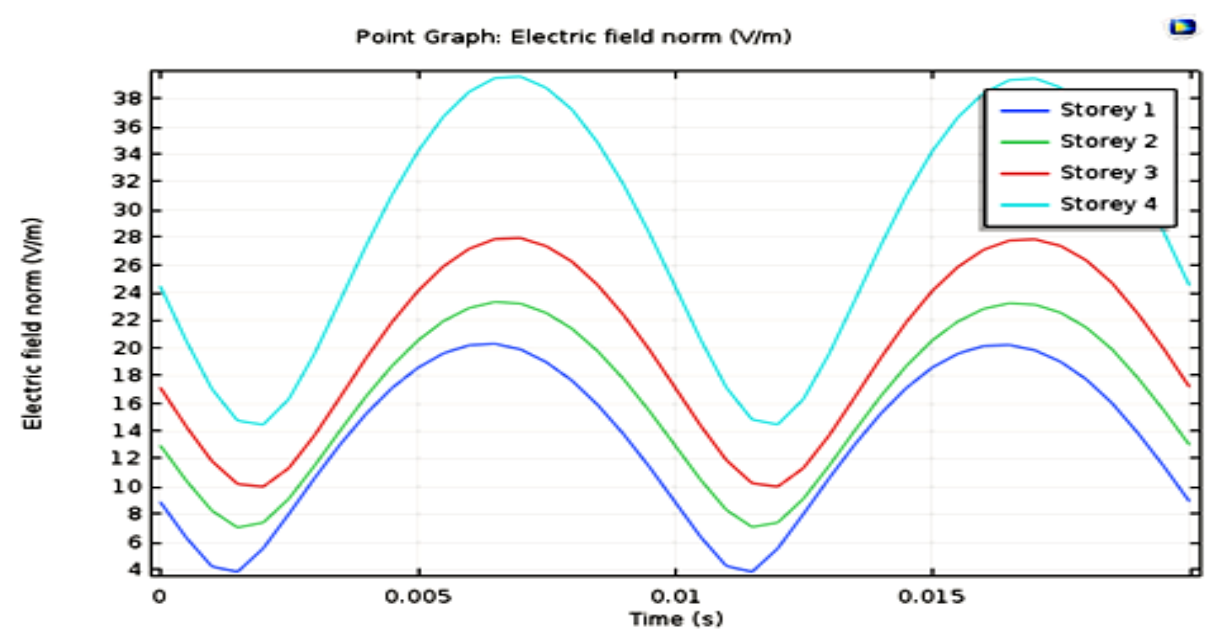

Figure 16. Maximum electric field value in different floors below the line axis 
Table 3. The Intensity of The Field in the Presence of Complete Cage

\begin{tabular}{|c|c|c|c|c|}
\hline $\begin{array}{c}\text { Scenario and Distance from } \\
\text { The Line Axis (meters) }\end{array}$ & $\begin{array}{c}\text { First Floor } \\
\left(\frac{\boldsymbol{V}}{\boldsymbol{m}}\right)\end{array}$ & $\begin{array}{c}\text { Second Floor } \\
\left(\frac{\boldsymbol{V}}{\boldsymbol{m}}\right)\end{array}$ & $\begin{array}{c}\text { Third Floor } \\
\left(\frac{\boldsymbol{V}}{\boldsymbol{m}}\right)\end{array}$ & $\begin{array}{c}\text { Fourth Floor } \\
\left(\frac{\boldsymbol{V}}{\boldsymbol{m}}\right)\end{array}$ \\
\hline $\begin{array}{c}\text { Below the Line Axis } \\
\text { (without cage) }\end{array}$ & 1340 & 2000 & 3370 & 6850 \\
\hline $\begin{array}{c}\text { Below the Line Axis } \\
\text { (complete cage) }\end{array}$ & 20 & 23 & 28 & 39 \\
\hline $\begin{array}{c}3 \text { meters } \\
\text { (without cage) }\end{array}$ & 1590 & 2485 & 4150 & 8350 \\
\hline $\begin{array}{c}3 \text { meters } \\
\text { (complete cage) }\end{array}$ & 29 & 34 & 41 & 78 \\
\hline $\begin{array}{c}\text { 6 meters } \\
\text { (without cage) }\end{array}$ & 1976 & 2691 & 4050 & 6380 \\
\hline $\begin{array}{c}\text { 6 meters } \\
\text { (complete cage) }\end{array}$ & 40 & 41 & 43 & 73 \\
\hline
\end{tabular}

Based on the simulation results, according to the diagrams and table 3, it is clear that the intensity of the electric field after placing the metal protector on different floors of the building has been drastically reduced and the protection operation has been done completely and well.

\section{Complete Cage ( $\Gamma$ Shape)}

The next scenario examined is the use of defective metal shields. This protection, which, unlike the complete cage, only covers the side wall and part of the roof, is $\Gamma$ shaped according to Figure 17, and its other specifications are the same as the full protection.

The results of the maximum field value in the classes and from different distances are shown in Figures 18 to 23.

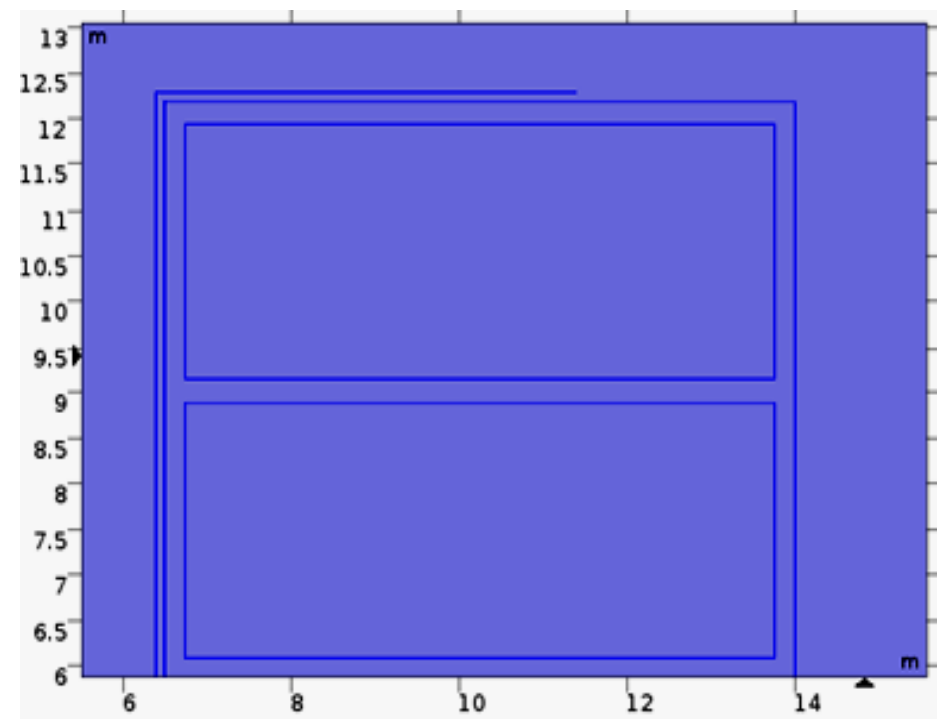

Figure 17. Incomplete cage ( $\Gamma$ shape) 


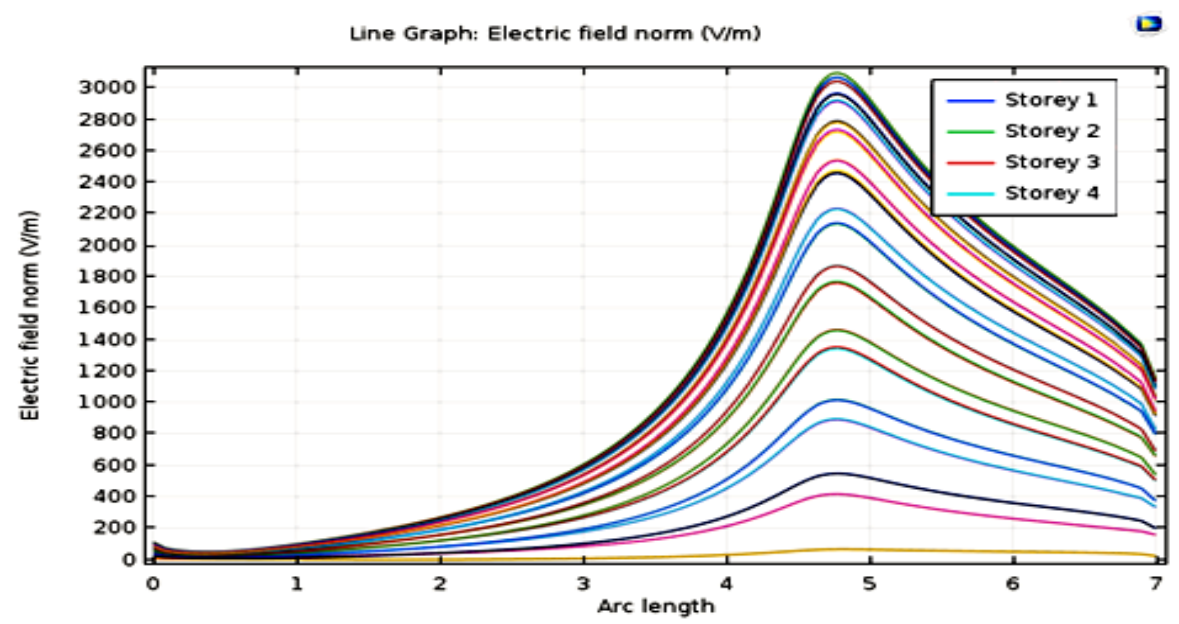

Figure 18. Maximum electric field value on the fourth floor (distance 6 meters)

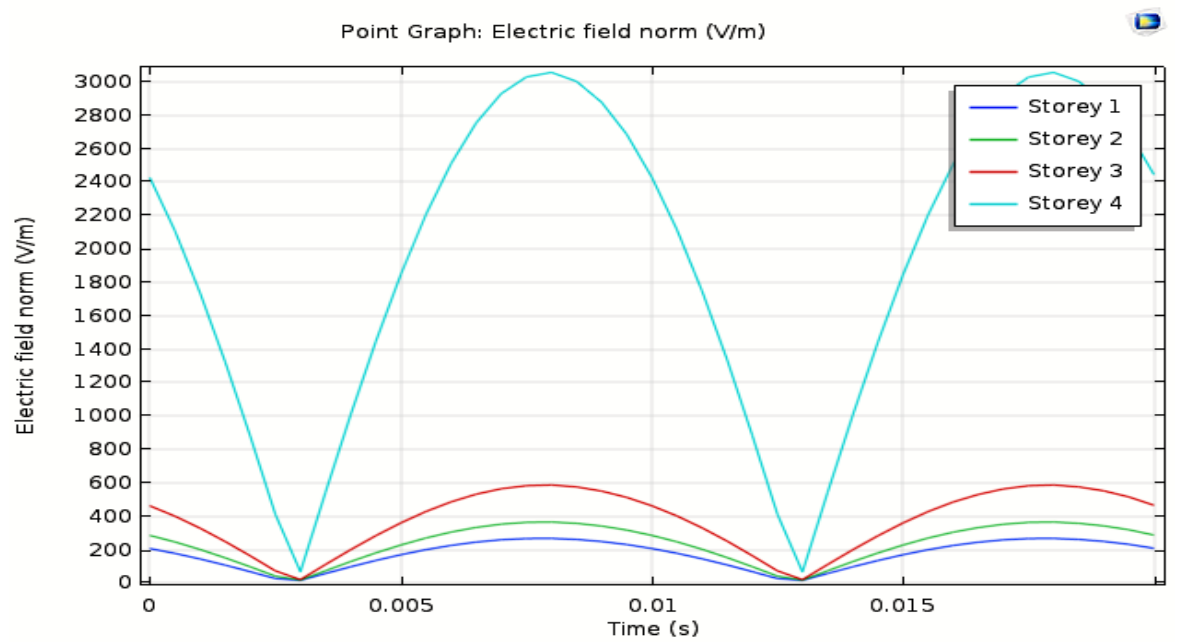

Figure 19. Maximum electric field value in different floors (distance 6 meters)

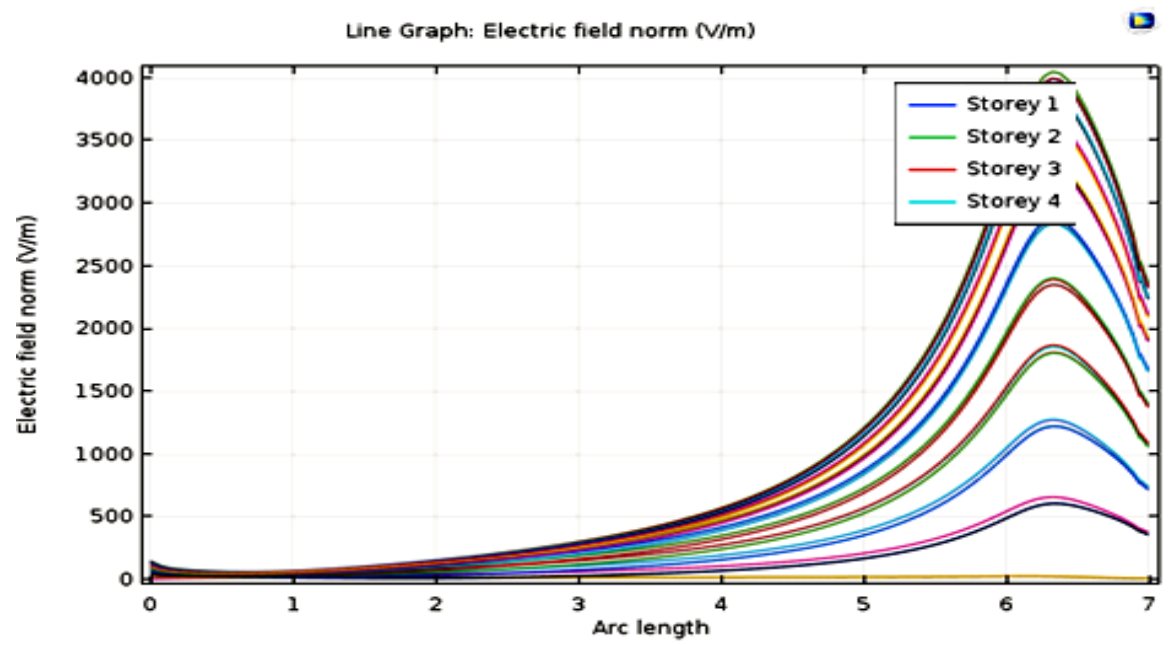

Figure 20. Maximum electric field value on the fourth floor (distance 3 meters) 


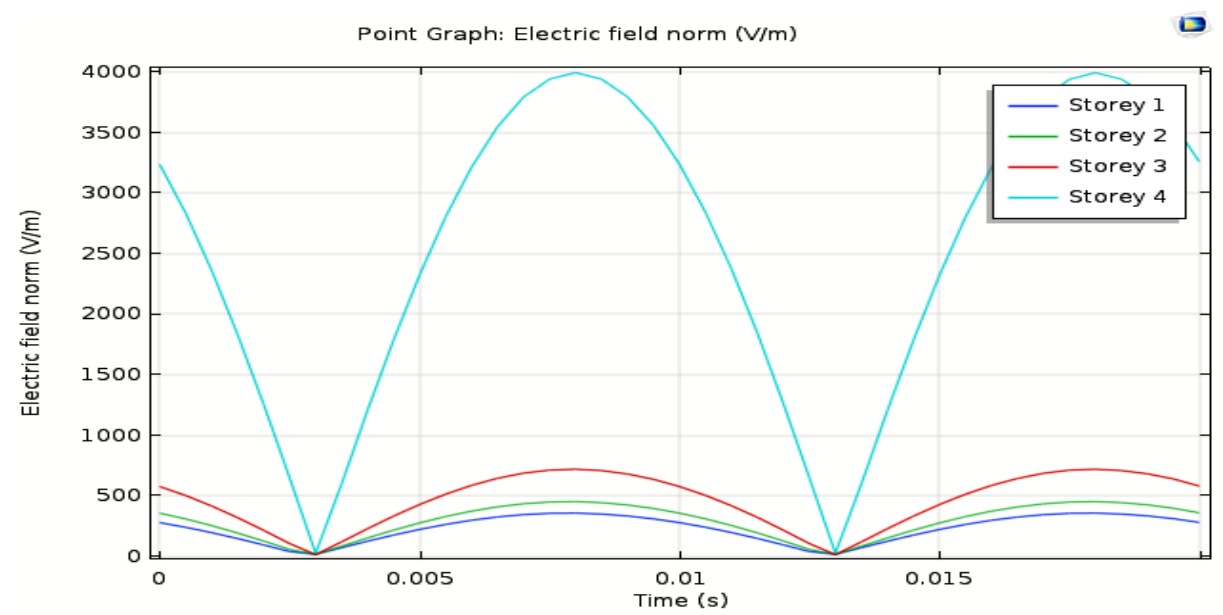

Figure 21. Maximum electric field value in different floors (distance 3 meters)

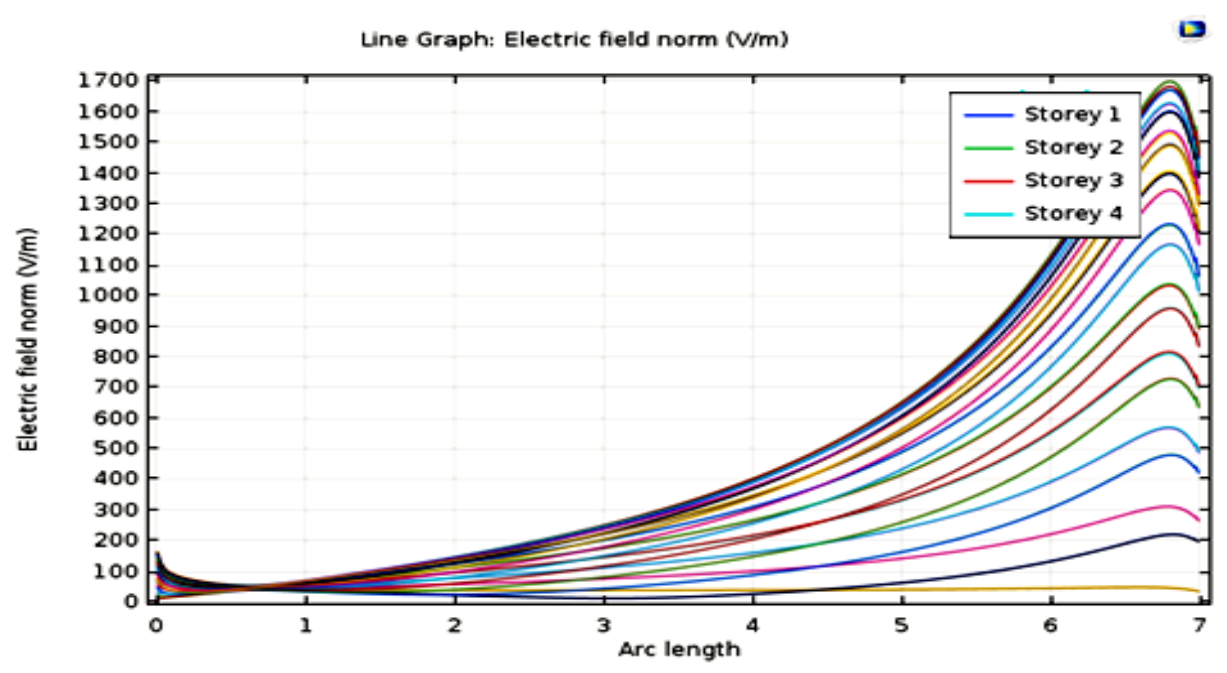

Figure 22. Maximum electric field value on the fourth floor below

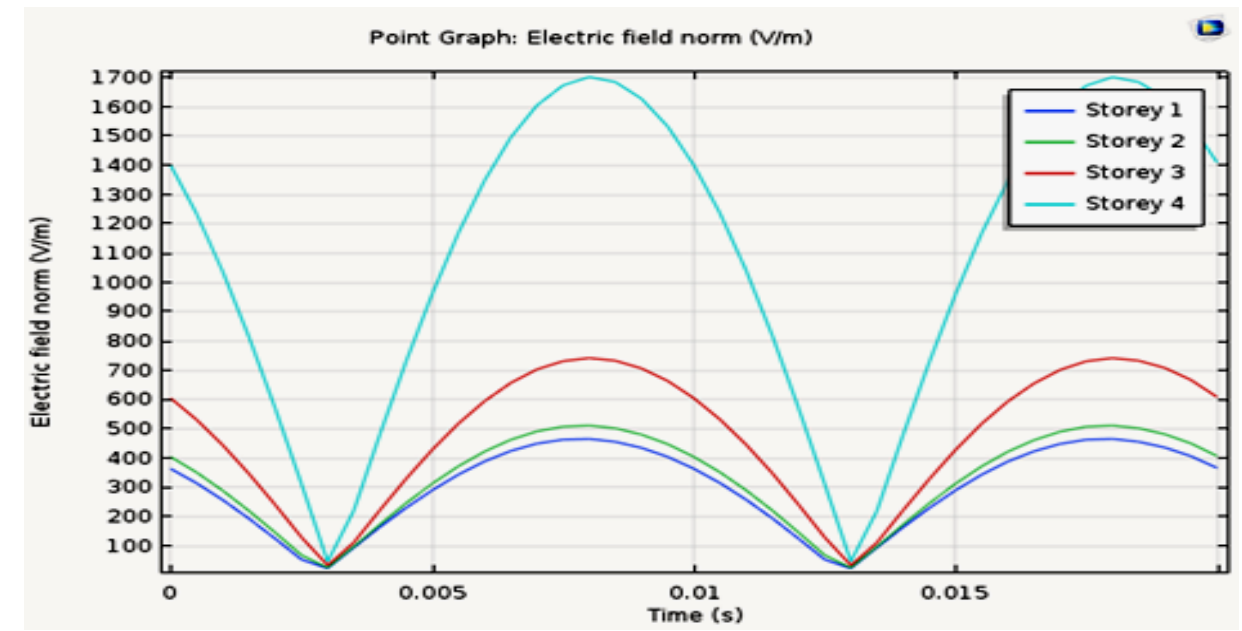

Figure 23. Maximum electric field value in different floors below the line axis 
Table 4. The Intensity of the Field in the Presence of Incomplete Cage ( $\Gamma$ shape)

\begin{tabular}{|c|c|c|c|c|}
\hline $\begin{array}{c}\text { Scenario and Distance from The } \\
\text { Line Axis (meters) }\end{array}$ & $\begin{array}{c}\text { First Floor } \\
\left(\frac{\boldsymbol{V}}{\boldsymbol{m}}\right)\end{array}$ & $\begin{array}{c}\text { Second Floor } \\
\left(\frac{\boldsymbol{V}}{\boldsymbol{m}}\right)\end{array}$ & $\begin{array}{c}\text { Third Floor } \\
\left(\frac{\boldsymbol{V}}{\boldsymbol{m}}\right)\end{array}$ & $\begin{array}{c}\text { Fourth Floor } \\
\left(\frac{\boldsymbol{V}}{\boldsymbol{m}}\right)\end{array}$ \\
\hline $\begin{array}{c}\text { Below the Line Axis } \\
\text { (without cage) }\end{array}$ & 1340 & 2000 & 3370 & 6850 \\
\hline $\begin{array}{c}\text { Below the Line Axis } \\
\text { Incomplete cage }(\Gamma \text { shape) }\end{array}$ & 485 & 500 & 745 & 1700 \\
\hline $\begin{array}{c}3 \text { meters } \\
(\text { without cage) }\end{array}$ & 1590 & 2485 & 4150 & 8350 \\
\hline $\begin{array}{c}3 \text { meters } \\
\text { Incomplete cage }(\Gamma \text { shape) }\end{array}$ & 480 & 500 & 740 & 3995 \\
\hline $\begin{array}{c}6 \text { meters } \\
(\text { without cage })\end{array}$ & 1976 & 2691 & 4050 & 6380 \\
\hline $\begin{array}{c}6 \text { meters } \\
\text { Incomplete cage }(\Gamma \text { shape) }\end{array}$ & 260 & 400 & 600 & 3050 \\
\hline
\end{tabular}

Based on the simulation results, according to the charts and Table 4, we see that in this case, in all three distances, the field value in all classes decreased, but this decrease was not the same in all classes so that in the lower classes it was more intense and in the fourth class the decrease was less.

\section{Incomplete Cage (Roofless)}

In the third scenario, we simulate a roofless metal guard following Figure 24 so that only the side walls of the building are protected and covered by a guard. The specifications of this protection are completely similar to the complete cage and its height is 14.2 from the ground. The results of the maximum field value in the classes and from different distances are shown in Figures 25 to 30.

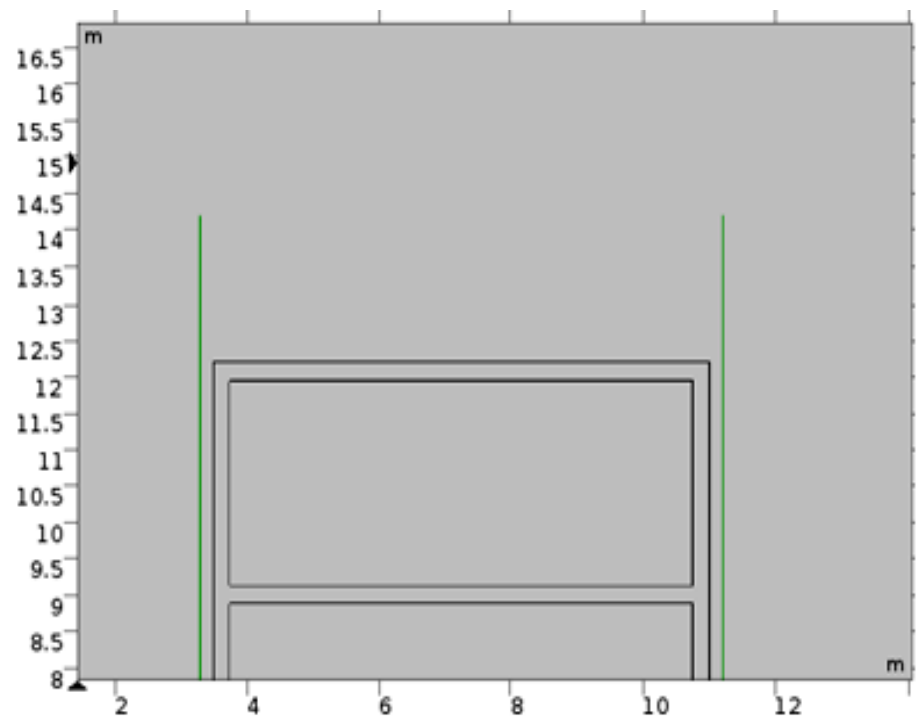

Figure 24. Incomplete cage (roofless) 


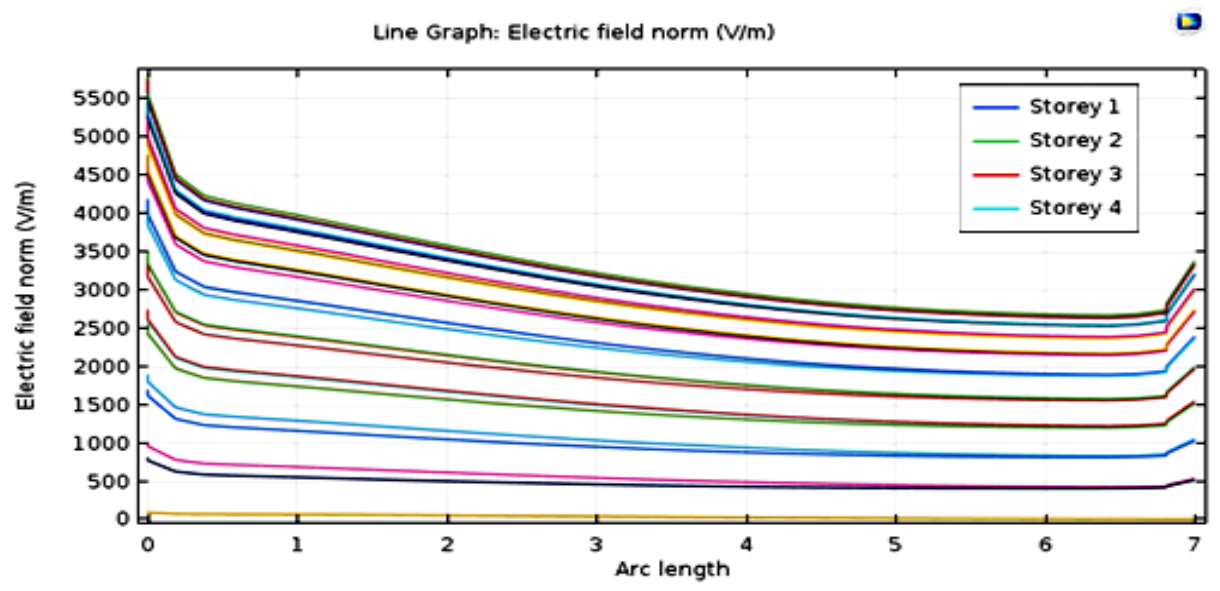

Figure 25. Maximum electric field strength on the fourth floor (distance 6 meters)

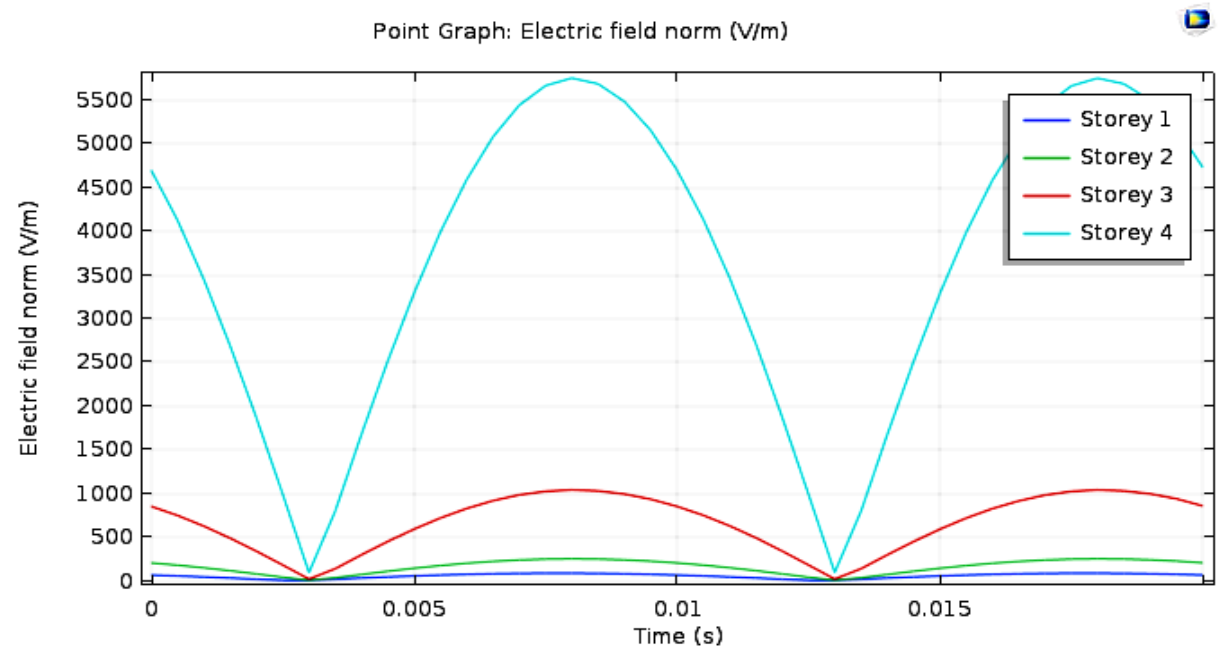

Figure 26. Maximum electric field value in different floors (distance 6 meters)

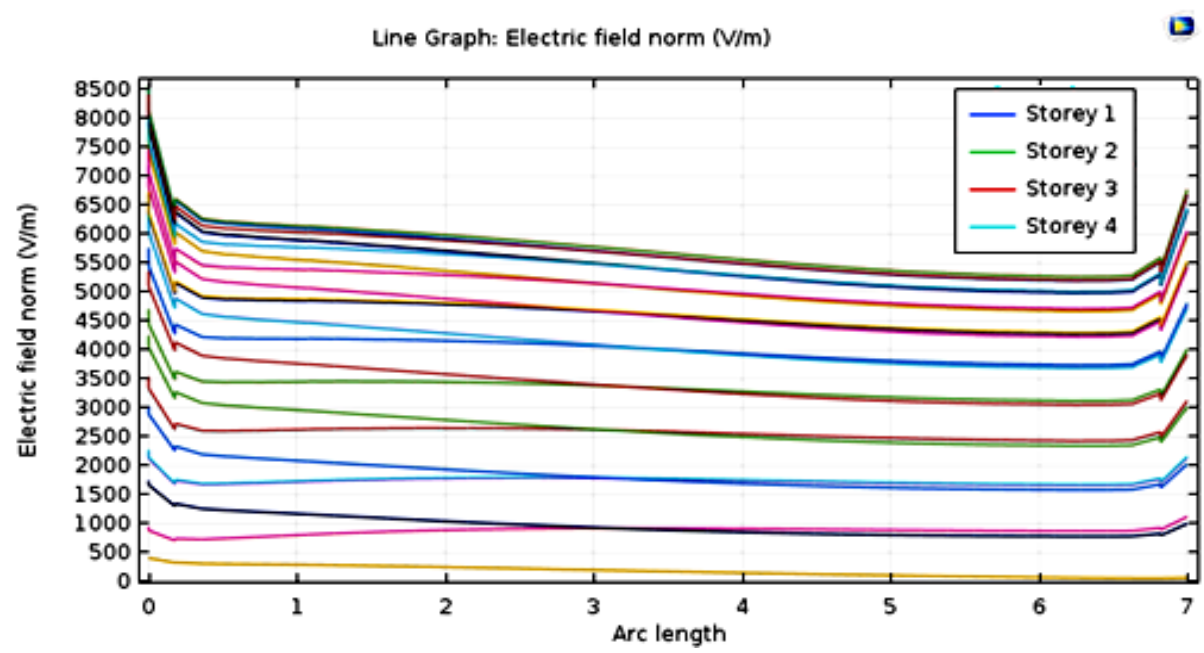

Figure 27. Maximum electric field values on the fourth floor (distance 3 meters) 


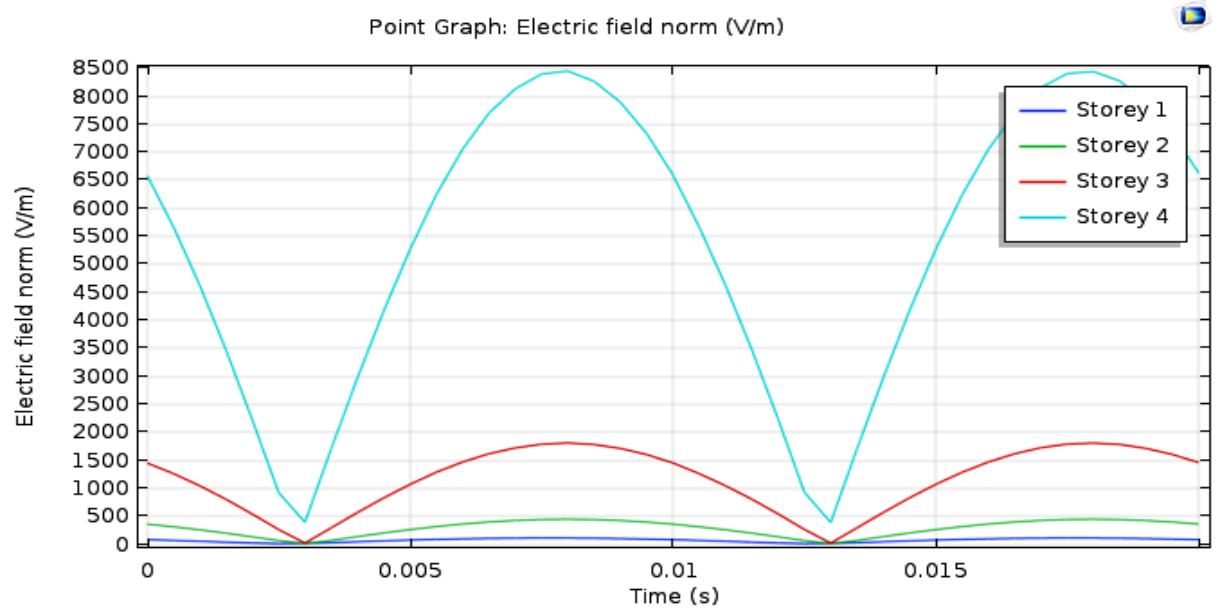

Figure 28. Maximum electric field value on the fourth floor (distance 3 meters)

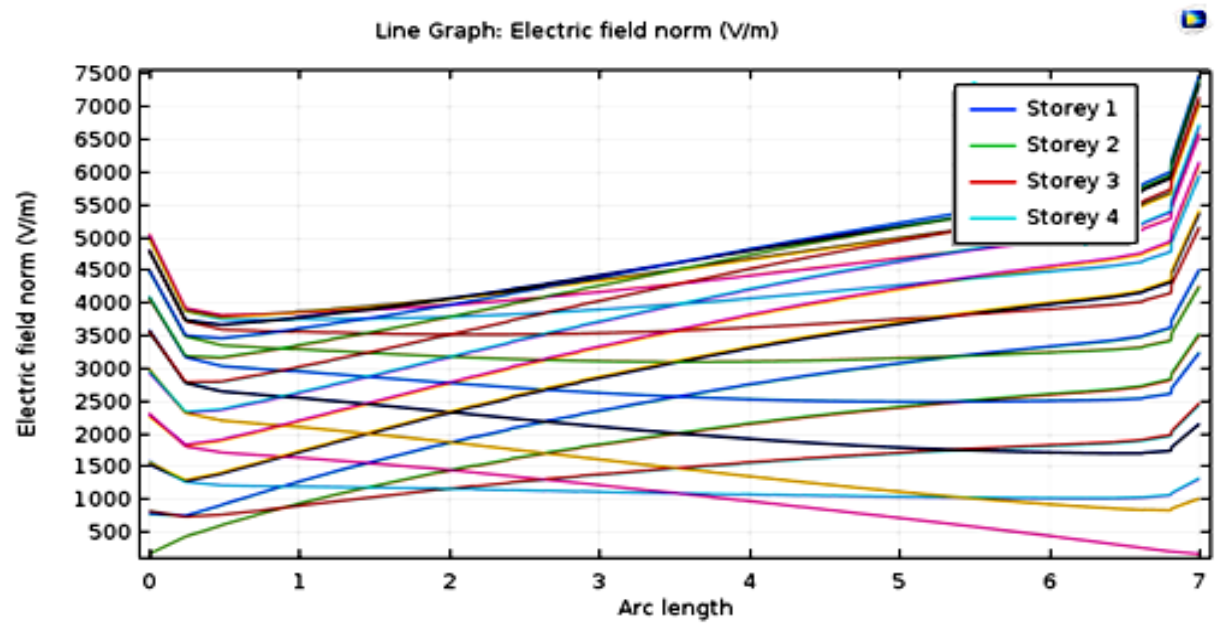

Figure 29. Maximum electric field values on the fourth floor below the line axis

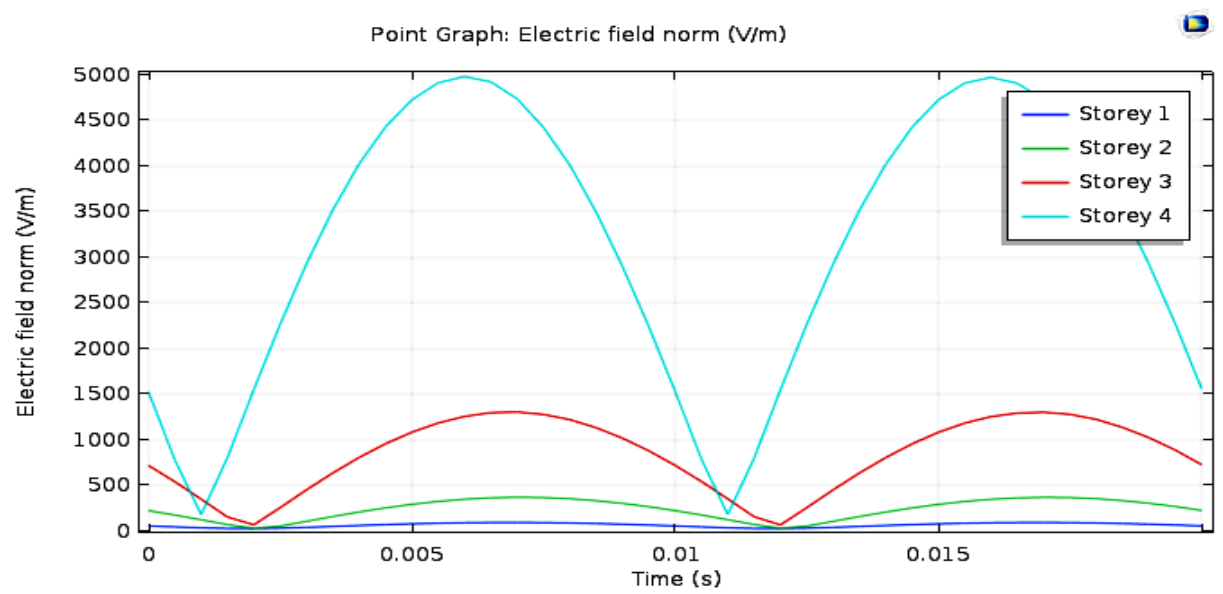

Figure 30. Maximum electric field value in different floors below the line axis 
Table 5. The Intensity of the Field in the Presence of Incomplete Cage (roofless)

\begin{tabular}{|c|c|c|c|c|}
\hline $\begin{array}{c}\text { Scenario and Distance from The } \\
\text { Line Axis (meters) }\end{array}$ & $\begin{array}{c}\text { First Floor } \\
\left(\frac{\boldsymbol{V}}{\boldsymbol{m}}\right)\end{array}$ & $\begin{array}{c}\text { Second Floor } \\
\left(\frac{\boldsymbol{V}}{\boldsymbol{m}}\right)\end{array}$ & $\begin{array}{c}\text { Third Floor } \\
\left(\frac{\boldsymbol{V}}{\boldsymbol{m}}\right)\end{array}$ & $\begin{array}{c}\text { Fourth Floor } \\
\left(\frac{\boldsymbol{V}}{\boldsymbol{m}}\right)\end{array}$ \\
\hline $\begin{array}{c}\text { Below the Line Axis } \\
\text { (without cage) }\end{array}$ & 1340 & 2000 & 3370 & 6850 \\
\hline $\begin{array}{c}\text { Below the Line Axis } \\
\text { Incomplete cage (roofless) }\end{array}$ & 102 & 375 & 1308 & 4977 \\
\hline $\begin{array}{c}3 \text { meters } \\
\text { (without cage) }\end{array}$ & 1590 & 2485 & 4150 & 8350 \\
\hline $\begin{array}{c}\text { 3 meters } \\
\text { Incomplete Cage (roofless) }\end{array}$ & 115 & 450 & 1814 & 8450 \\
\hline $\begin{array}{c}\text { 6 meters } \\
\text { (without cage) }\end{array}$ & 1976 & 2691 & 4050 & 6380 \\
\hline $\begin{array}{c}\text { 6 meters } \\
\text { Incomplete Cage (roofless) }\end{array}$ & 98 & 255 & 1045 & 5750 \\
\hline
\end{tabular}

Looking at the simulation results, diagrams, and Table 5, we can say that in this case, the changes in the field value of the fourth floor have fluctuated at different distances, so that we have witnessed a decrease in the field intensity in the center and 6 meters from the line, while in the distance of 3 meters the intensity of the field has slightly increased.

Also, the common denominator of field changes at all intervals is the noticeable reduction of the field in the lower classes.

\section{Painting}

Another solution that is being considered is the use of paints containing carbon nano particles. According to Figure 31, in this simulation, all the outer surfaces of the building are covered with this paint with a thickness of $1 \mathrm{~mm}$.

The results of the maximum field value in the classes and from different distances are shown in Figure 32 to 37.

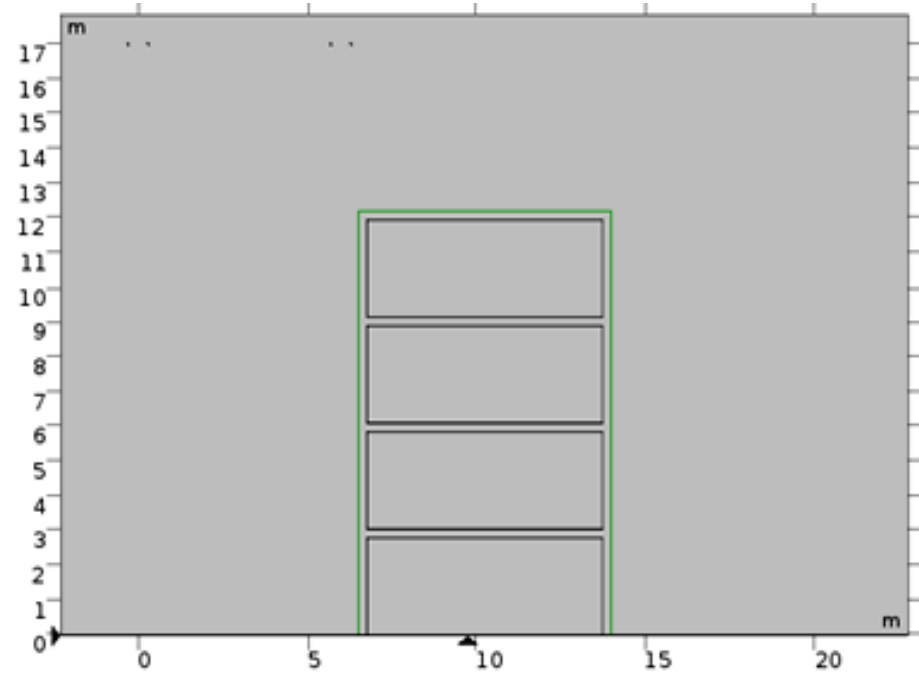

Figure 31. Conductive painting model 


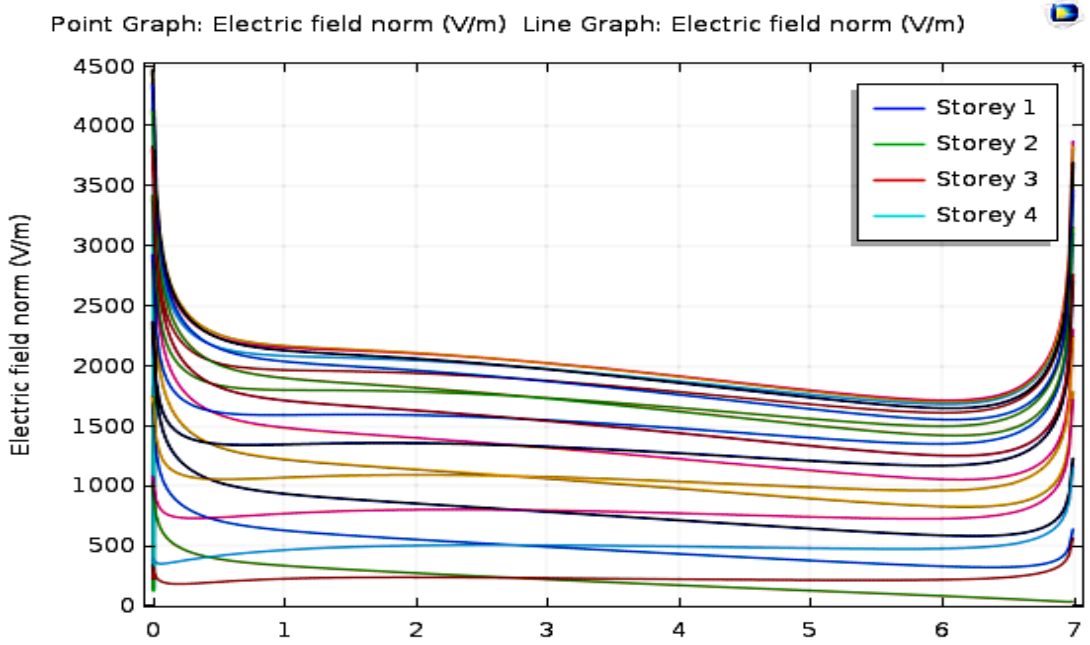

Figure 32. Maximum electric field values on the fourth floor (distance 6 meters)

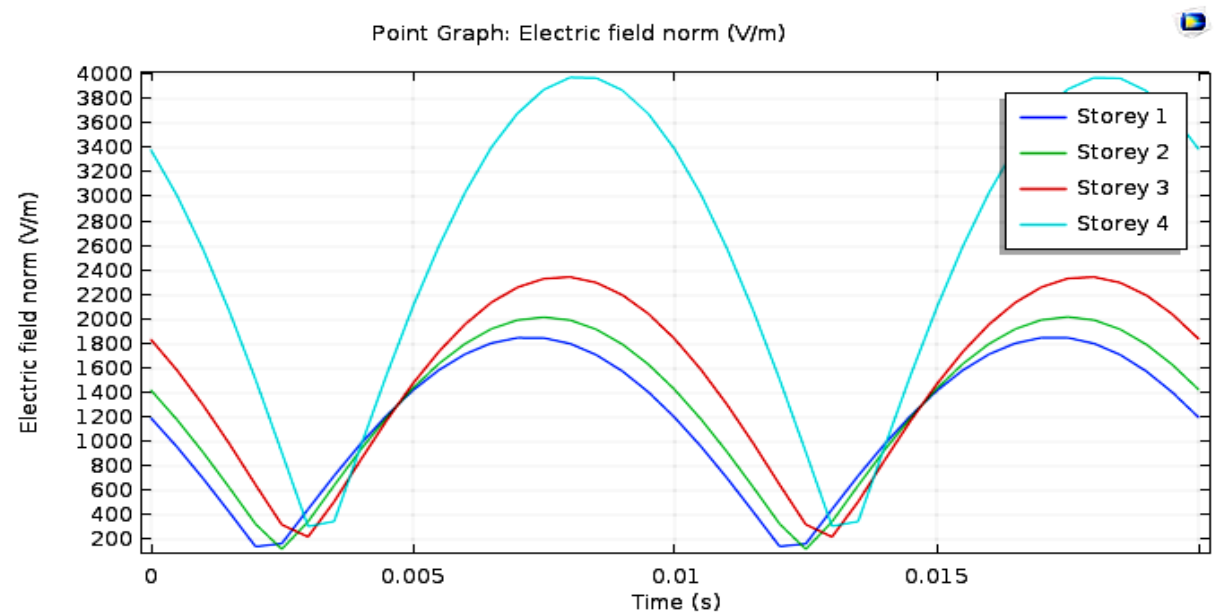

Figure 33. Maximum electric field value in different floors (distance 6 meters)

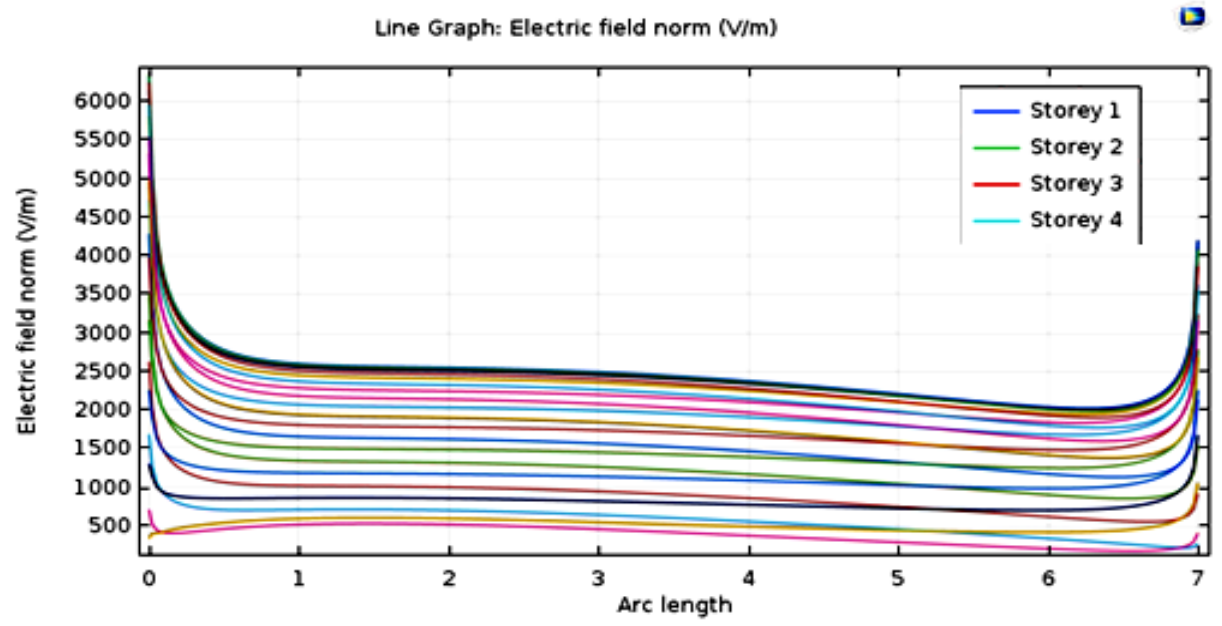

Figure 34. Maximum electric field values on the fourth floor (distance 3 meters) 


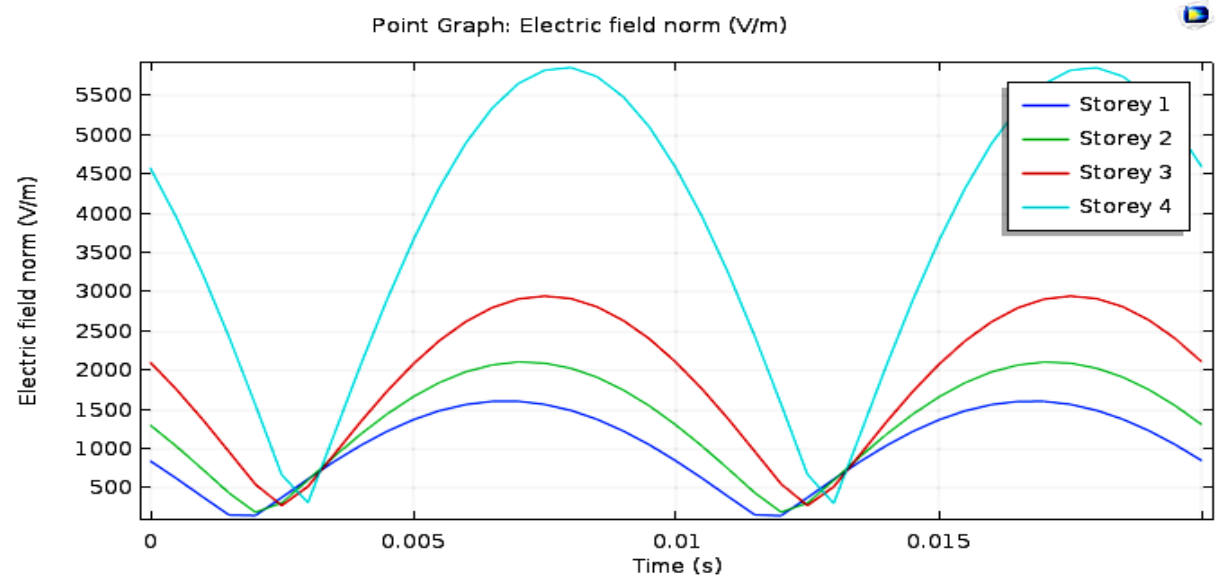

Figure 35. Maximum electric field values in different floors (distance 3 meters)

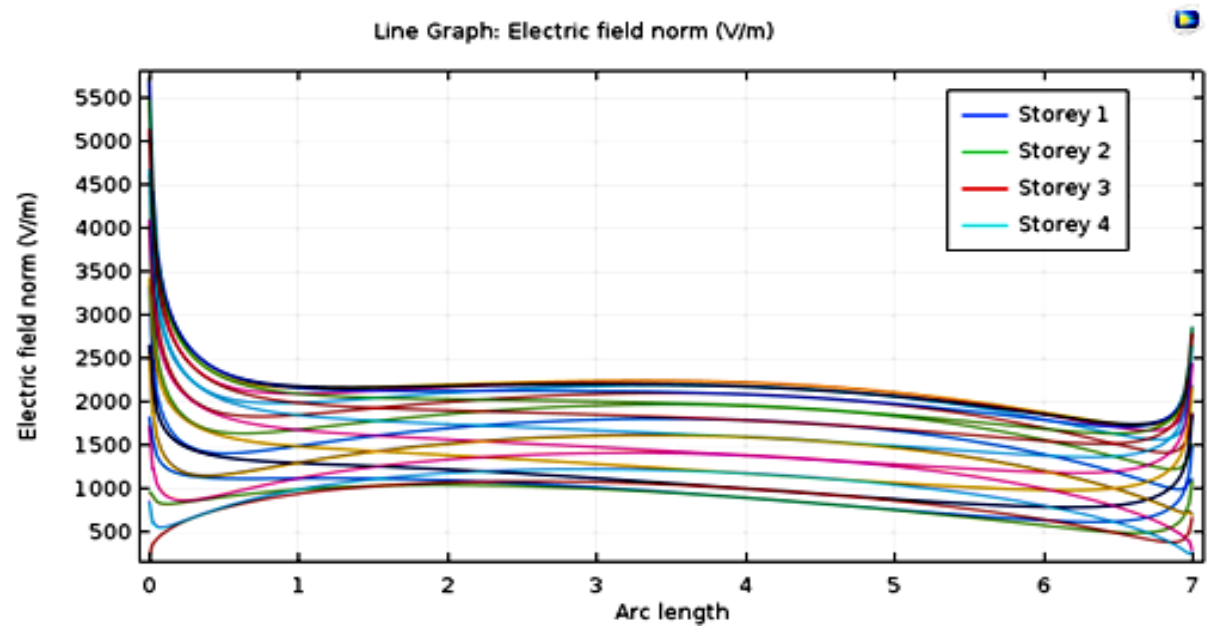

Figure 36. Maximum electric field value on the fourth floor below the line axis

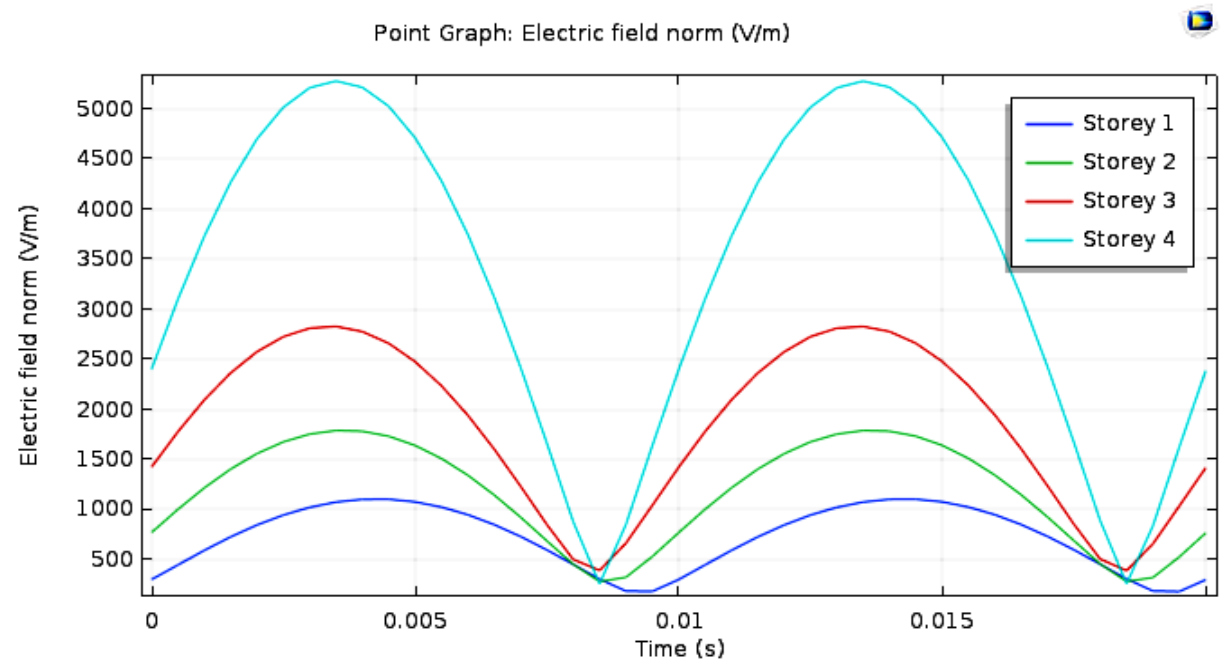

Figure 37. Maximum electric field value in different floors below the line axis 
Table 6. The Intensity of the Field in the Presence of Conductive Painting

\begin{tabular}{|c|c|c|c|c|}
\hline $\begin{array}{c}\text { Scenario and Distance from The } \\
\text { Line Axis (meters) }\end{array}$ & $\begin{array}{c}\text { First Floor } \\
\left(\frac{\boldsymbol{V}}{\boldsymbol{m}}\right)\end{array}$ & $\begin{array}{c}\text { Second Floor } \\
\left(\frac{\boldsymbol{V}}{\boldsymbol{m}}\right)\end{array}$ & $\begin{array}{c}\text { Third Floor } \\
\left(\frac{\boldsymbol{V}}{\boldsymbol{m}}\right)\end{array}$ & $\begin{array}{c}\text { Fourth Floor } \\
\left(\frac{\boldsymbol{V}}{\boldsymbol{m}}\right)\end{array}$ \\
\hline $\begin{array}{c}\text { Below the Line Axis } \\
\text { (without cage) }\end{array}$ & 1340 & 2000 & 3370 & 6850 \\
\hline $\begin{array}{c}\text { Below the Line Axis } \\
\text { (painting) }\end{array}$ & 1100 & 1789 & 2826 & 5277 \\
\hline $\begin{array}{c}\text { 3 meters } \\
\text { (without cage) }\end{array}$ & 1590 & 2485 & 4150 & 8350 \\
\hline $\begin{array}{c}\text { 3 meters } \\
\text { (painting) }\end{array}$ & 1610 & 2112 & 2950 & 5850 \\
\hline $\begin{array}{c}\text { 6 meters } \\
\text { (without cage) }\end{array}$ & 1976 & 2691 & 4050 & 6380 \\
\hline $\begin{array}{c}\text { 6 meters } \\
\text { (painting) }\end{array}$ & 1850 & 2020 & 2347 & 3980 \\
\hline
\end{tabular}

By looking at the simulation results, the diagrams and Table 6 about the color of the conductor are clear. In most of the different floors and distances except the first floor at a distance of 3 meters, the field value has decreased. But there are two notable points: on the first, second, and third floors, the decline is small, and on the fourth floor, where the rate of decline has been significant, the intensity of the field is still high.

\section{The Effect of Tree}

Finally, the effect of the presence of the tree on the intensity of the floor square is examined. In this simulation, according to Figure 38, a tree with a height of 6 meters is located at a distance of $20 \mathrm{~cm}$ from the wall of the building.

The results of the maximum field value in the classes and from different distances are shown in Figures 39 to 44.

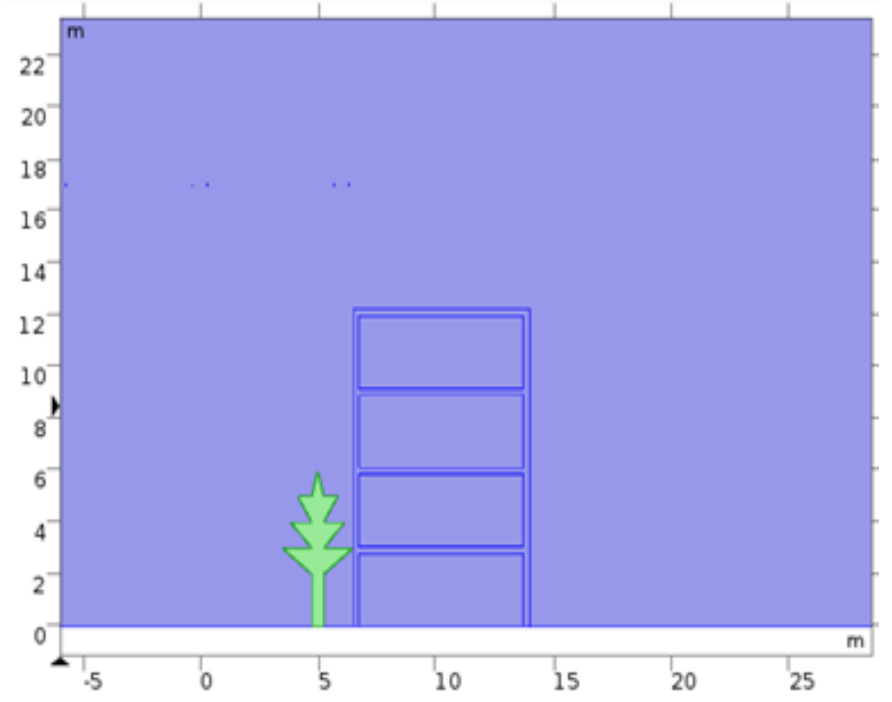

Figure 38. Conductive painting model 


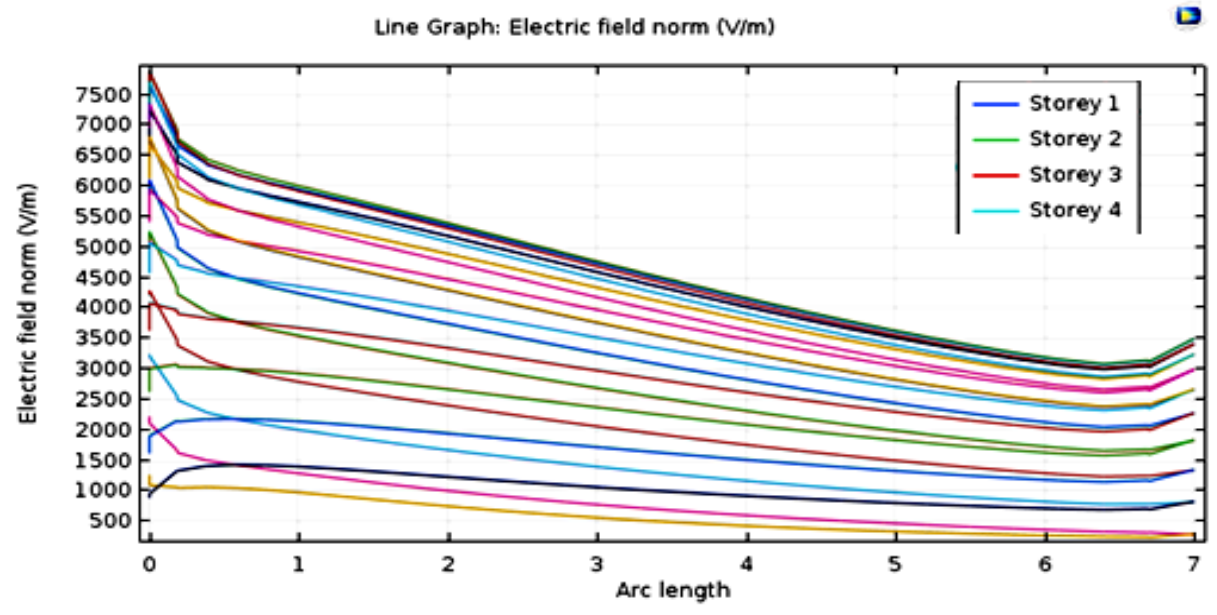

Figure 39. Maximum electric field values on the fourth floor (distance 6 meters)

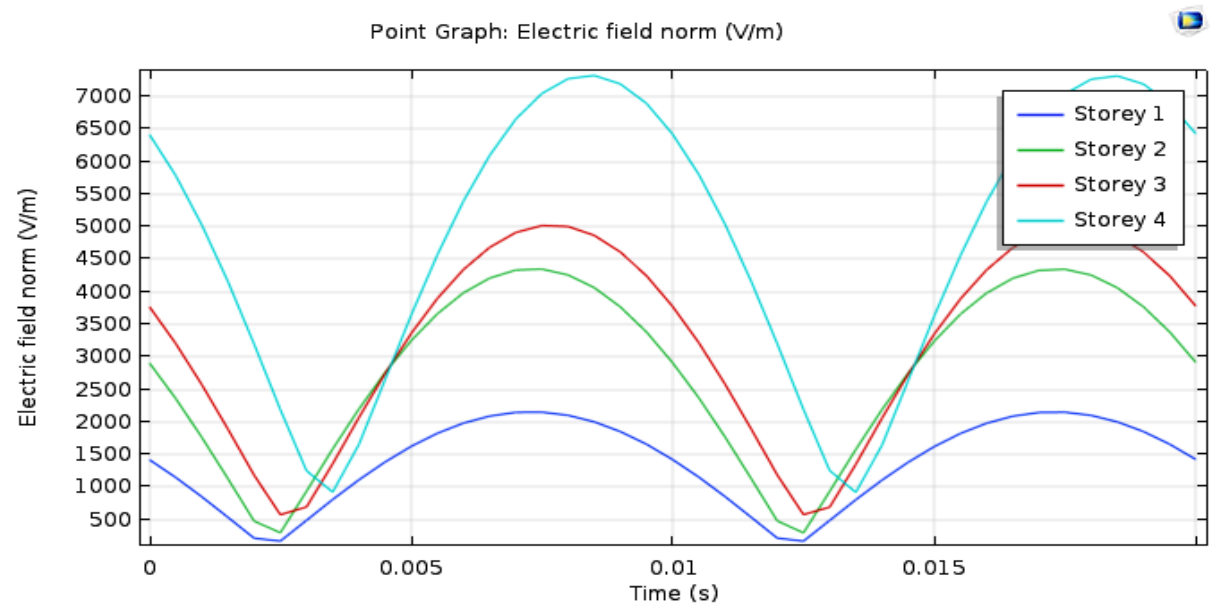

Figure 40. Maximum electric field value in different floors (distance 6 meters)

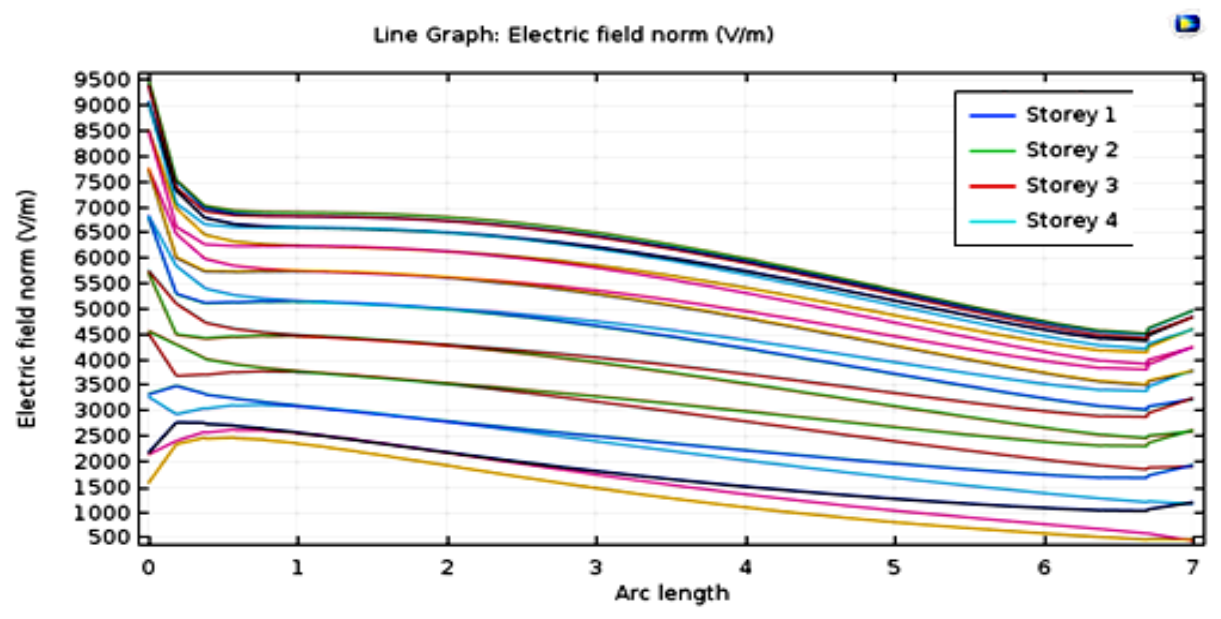

Figure 41. Maximum electric field value on the fourth floor (distance 3 meters) 


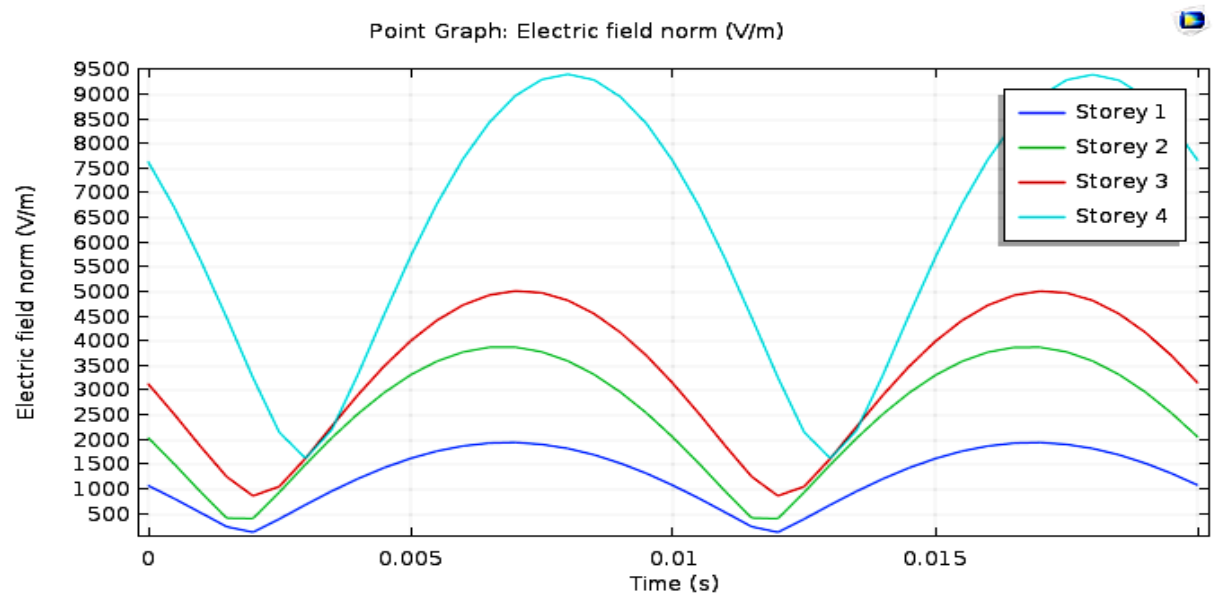

Figure 42. Maximum electric field value in different floors (distance 3 meters)

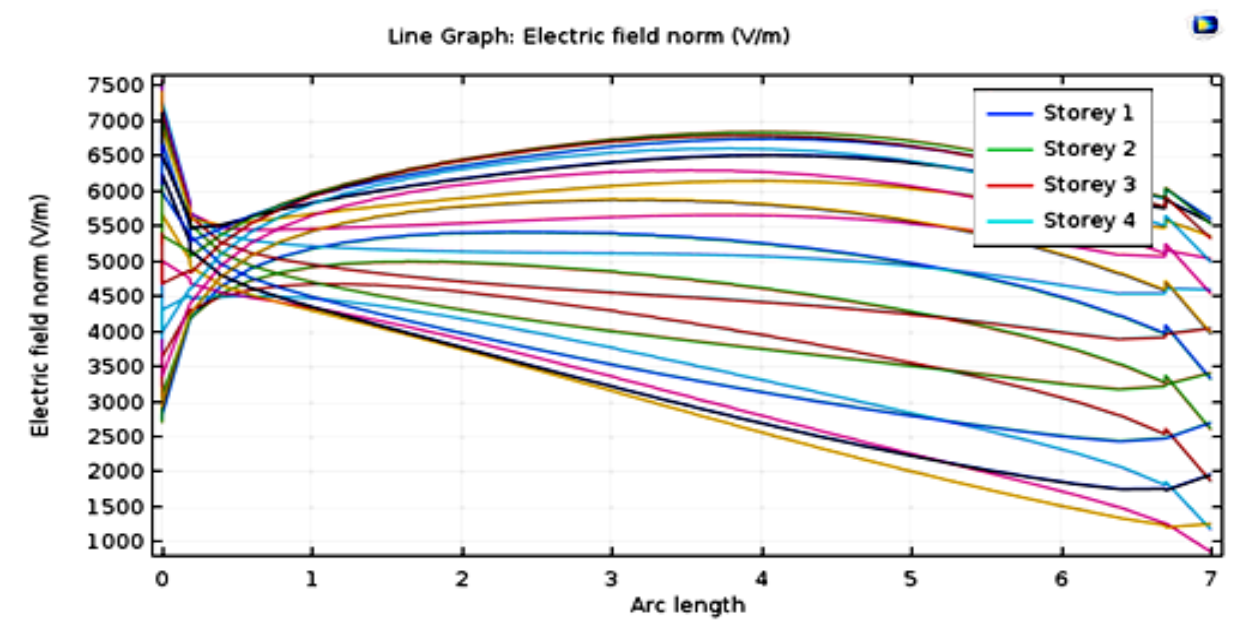

Figure 43. Maximum electric field values on the fourth floor below the line axis

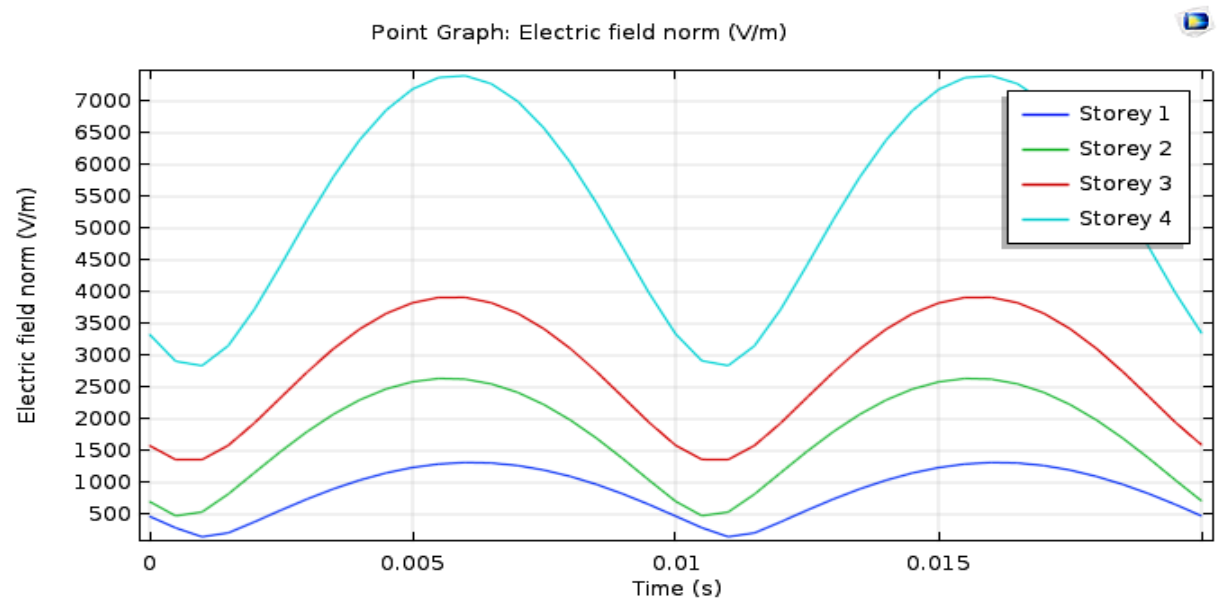

Figure 44. Maximum electric field value in different floors below the line axis 
Table 7. The Intensity of the Field in the Presence of Tree

\begin{tabular}{|c|c|c|c|c|}
\hline $\begin{array}{c}\text { Scenario and Distance from The } \\
\text { Line Axis (meters) }\end{array}$ & $\begin{array}{c}\text { First Floor } \\
\left(\frac{\boldsymbol{V}}{\boldsymbol{m}}\right)\end{array}$ & $\begin{array}{c}\text { Second Floor } \\
\left(\frac{\boldsymbol{V}}{\boldsymbol{m}}\right)\end{array}$ & $\begin{array}{c}\text { Third Floor } \\
\left(\frac{\boldsymbol{V}}{\boldsymbol{m}}\right)\end{array}$ & $\begin{array}{c}\text { Fourth Floor } \\
\left(\frac{\boldsymbol{V}}{\boldsymbol{m}}\right)\end{array}$ \\
\hline $\begin{array}{c}\text { Below the Line Axis } \\
\text { (without cage) }\end{array}$ & 1340 & 2000 & 3370 & 6850 \\
\hline $\begin{array}{c}\text { Below the Line Axis } \\
\text { (tree) }\end{array}$ & 1317 & 2650 & 3915 & 7400 \\
\hline $\begin{array}{c}3 \text { meters } \\
\text { (without cage) }\end{array}$ & 1950 & 3900 & 5025 & 8350 \\
\hline $\begin{array}{c}3 \text { meters } \\
\text { (tree) }\end{array}$ & 1976 & 2691 & 4050 & 6300 \\
\hline $\begin{array}{c}6 \text { meters } \\
\text { (without cage) }\end{array}$ & 2100 & 4367 & 5020 & 7300 \\
\hline $\begin{array}{c}6 \text { meters } \\
\text { (tree) }\end{array}$ & & 2485 & 6300 \\
\hline
\end{tabular}

Observing the simulation results, the graphs and Table 7, contrary to the expectations of the results of the study of the impact of the tree on all floors and distances except the first floor below the line axis, show an increase in field intensity in the presence of the tree. And instead of being a factor in reducing waves, it increases the electric field value.

\section{Discussion and Conclusions}

Based on the simulation results, we clearly saw that the field value of the fourth floor at a distance of 0,3 , and 6 meters from the line axis violates the allowable limit of the set standards, so we provided solutions to reduce the field value. Comparison of complete cage shielding, Incomplete cage ( $\Gamma$ shape) shielding, Incomplete cage (roofless)shielding, and conductive painting solutions conduction at 0,3 , and6 meters intervals are presented in Figures 45, 46, and 47. The red color is for normal mode, the black color is for conductive painting mode, the green color is for Incomplete cage (roofless) mode, the purple color is for Incomplete cage ( $\Gamma$ shape) mode and the blue color is for complete cage mode.

The first solution was to use a complete cage shielding, such as a Faraday cage, to protect against electromagnetic waves, which led to a sharp drop in the field on all floors and distances, which can be considered an ideal protector. It should be noted that the economic justification of projects is always one of the important points and tries to achieve the desired performance with the least cost, in this regard, we examined two smaller and cheaper modes of this complete protection. The first case was the use of a $\Gamma$ shape shielding, and as can be seen, the results of the simulation showed a decrease in field value in all classes.In this case, the decrease in field value in the first, second, and third classes was very severe and similar to the complete protection, and on the fourth floor, although the field value did not decrease as much as in the other classes, the field value decreased to an acceptable level. The second case was the use of roofless shielding, the results of which showed a decrease in field value in the first, second and third floors like the previous cases and for the fourth floor, the field value reduction was very small and even at a distance of 3 meters from the axis of the line is slightly increased. 


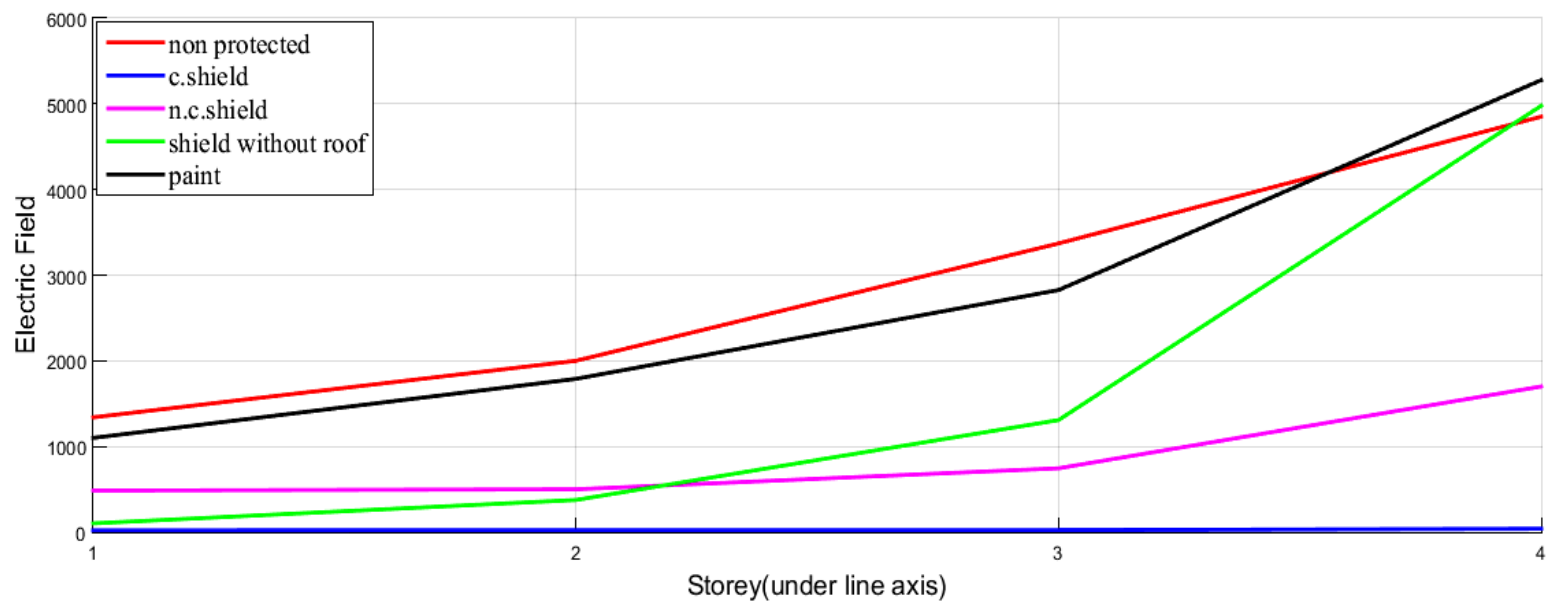

Figure 45. Comparison of field intensity reduction strategies from different classes below the line axis

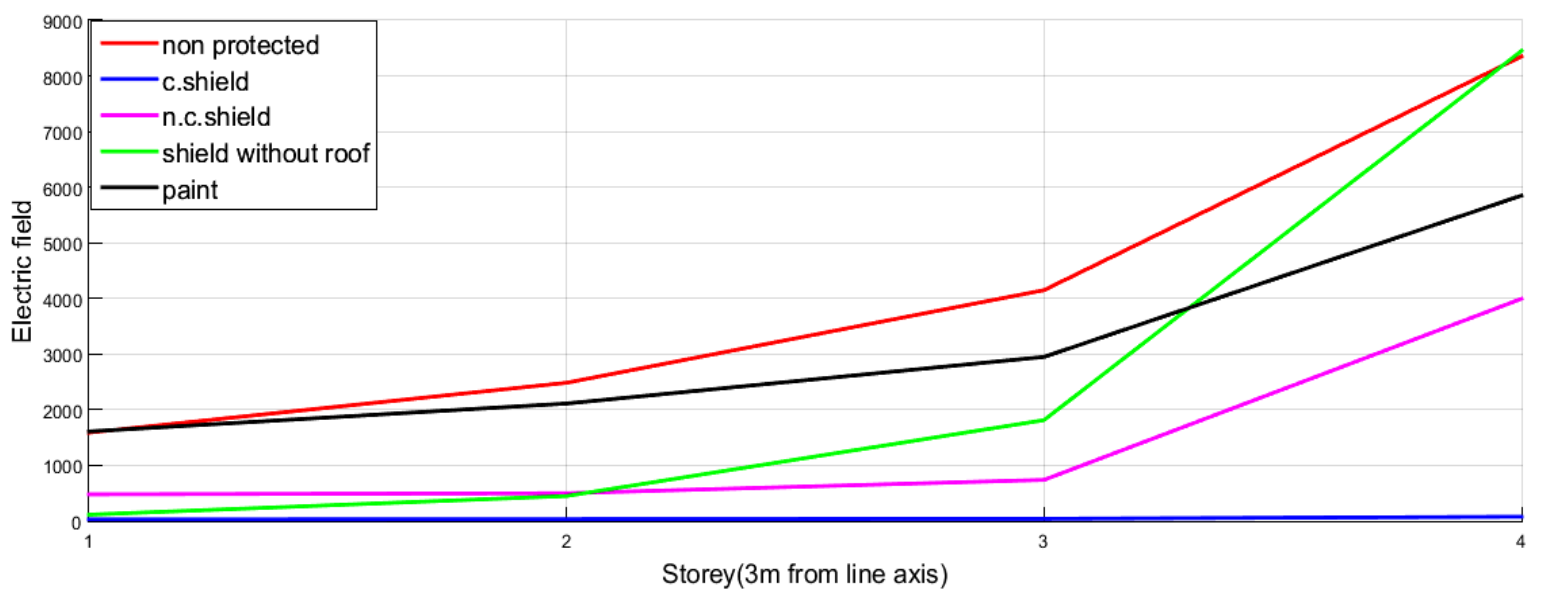

Figure 46 Comparison of field intensity reduction strategies from different classes at a distance of $3 \mathrm{~m}$

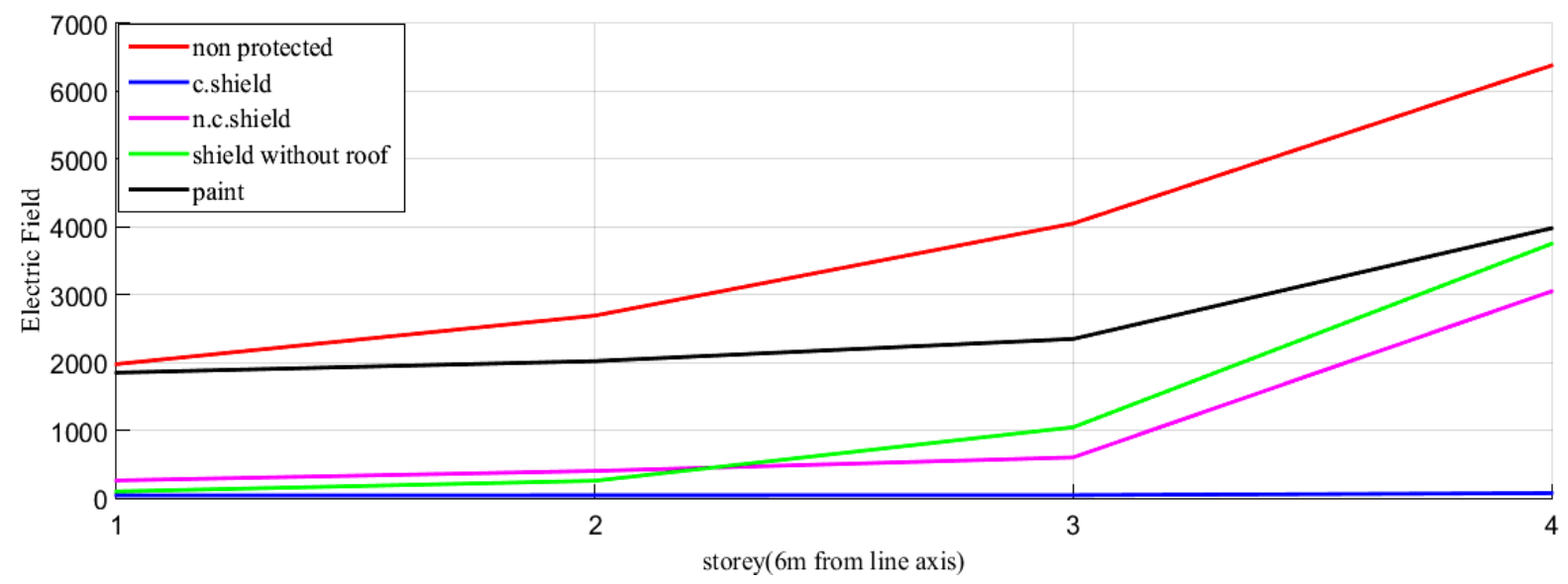

Figure 47. Comparison of field intensity reduction strategies from different classes at a distance of $6 \mathrm{~m}$ 
After examining the different cases of metal shielding, the method of using conductive paint containing carbon nano particles was investigated and the results showed that although the field value in the fourth and third floors has decreased significantly, the field value is still at the critical level. And in the first and second floors, the intensity of the decrease has been less than the upper floors, and even in one case, on the first floor, the distance of 3 meters from the intensity of the field has increased slightly.

In the end, the effect of tree presence on field arrangement was investigated and while we expected the field intensity to decrease and the tree to absorb electromagnetic waves, we witnessed an increase in field intensity in all classes. Therefore, this paper did not find any scientific findings based on tree protection against electromagnetic radiation.

As we know, depending on the type of building use and the sensitivities prevailing, the optimal option for protection against field value varies, but for this issue and without considering the specific conditions, it can be said that given the complete protection mode, a large amount of coverage metal is needed, and this high level of protection is not necessary, it is not a priority in the selection and there is no economic justification. Regarding the $\Gamma$ shape protection and roofless protection, it can be said that considering that the level of protection in the lower floors in both is almost equal, the protective function on the fourth floor is the most important criterion for comparison, from this point of view, reducing the field value on the one hand and reducing the use of metal shielding on the other hand makes the $\Gamma$ shape protection more justifiable and economical than roofless protection. Therefore, the $\Gamma$ shape protection solution is the most desirable and economical way to protect against field value and electromagnetic waves. Finally results from the comparison between all strategies are presented in the form of Table 8 .

Table 8. The Results from Comparison between All Strategies (all in $\frac{V}{m}$ )

\begin{tabular}{|c|c|c|c|c|c|}
\hline $\begin{array}{l}\text { Scenario and Distance } \\
\text { from The Line Axis } \\
\text { First Floor(meters) }\end{array}$ & $\begin{array}{l}\text { Complete } \\
\text { Cage }\end{array}$ & $\begin{array}{c}\text { Incomplete } \\
\text { Cage ( } \Gamma \text { shape })\end{array}$ & $\begin{array}{c}\text { Incomplete } \\
\text { Cage (roofless) }\end{array}$ & Painting & Tree \\
\hline Below the Line Axis & 20 & 485 & 102 & 1100 & 1317 \\
\hline 3 meters & 29 & 480 & 115 & 1610 & 1950 \\
\hline 6 meters & 40 & 260 & 98 & 1850 & 2100 \\
\hline $\begin{array}{l}\text { Scenario and Distance } \\
\text { from The Line Axis } \\
\text { Second Floor(meters) }\end{array}$ & $\begin{array}{l}\text { Complete } \\
\text { Cage }\end{array}$ & $\begin{array}{c}\text { Incomplete } \\
\text { Cage( } \Gamma \text { shape) }\end{array}$ & $\begin{array}{c}\text { Incomplete } \\
\text { Cage (roofless) }\end{array}$ & Painting & Tree \\
\hline Below the Line Axis & 23 & 500 & 375 & 1789 & 2650 \\
\hline 3 meters & 34 & 500 & 450 & 2112 & 3900 \\
\hline 6 meters & 41 & 400 & 255 & 2020 & 4367 \\
\hline $\begin{array}{l}\text { Scenario and Distance } \\
\text { from The Line Axis } \\
\text { Third Floor(meters) }\end{array}$ & $\begin{array}{l}\text { Complete } \\
\text { Cage }\end{array}$ & $\begin{array}{c}\text { Incomplete } \\
\text { Cage }(\Gamma \text { shape })\end{array}$ & $\begin{array}{c}\text { Incomplete } \\
\text { Cage (roofless) }\end{array}$ & Painting & Tree \\
\hline Below the Line Axis & 28 & 745 & 1308 & 2826 & 3915 \\
\hline 3 meters & 41 & 740 & 1814 & 2950 & 5025 \\
\hline 6 meters & 43 & 600 & 1045 & 2347 & 5020 \\
\hline
\end{tabular}




\begin{tabular}{|c|c|c|c|c|c|}
\hline $\begin{array}{c}\text { Scenario and Distance } \\
\text { from The Line Axis } \\
\text { Fourth Floor(meters) }\end{array}$ & $\begin{array}{c}\text { Complete } \\
\text { Cage }\end{array}$ & $\begin{array}{c}\text { Incomplete } \\
\text { Cage }(\boldsymbol{\Gamma} \text { shape) }\end{array}$ & $\begin{array}{c}\text { Incomplete } \\
\text { Cage (roofless) }\end{array}$ & Painting & Tree \\
\hline Below the Line Axis & 39 & 1700 & 4977 & 5277 & 7400 \\
\hline 3 meters & 78 & 3995 & 8450 & 5850 & 9400 \\
\hline 6 meters & 73 & 3050 & 5750 & 3980 & 7300 \\
\hline
\end{tabular}

\section{References}

[1] R. Katz, M. Biesele, and V. Denis, Healing Makes our Hearts Happy: Spirituality and Cultural, Inner Traditions, United States, 1997.

[2] F.G. Shellock, Magnetic Resonance Procedures: Health Effects and Safety, CRC Press, United States, 2000.

[3] P. Levallois, "Hypersensitivity of human subjects to environmental electric and magnetic field exposure: a review of the literature," Environmental Health Perspectives, Vol. 110, pp. 613-618, 2002. doi: 10.1289/ehp.02110s4613

[4] T. Viheriäkoski, R. Wong, R. Fung, and P. Tamminen, "Characterization of ESD shielding materials with novel test methods," IOP Journal of Physics: Conference Series 1322, pp. 1-4, 2019. doi: 10.1088/1742-6596/1322/1/012023

[5] Y. Yao, S. Jin, H. Zou, L. Li, X. Ma, G. Lv, F. Gao, X. Lv, and Q. Shu, "Polymer-based lightweight materials for electromagnetic interference shielding: A review," Journal of Materials Science, Vol. 56, pp. 6549-6580, 2021. doi: 10.1007/s10853-020-05635-x.

[6] T.E. Aldrich, and C.E. Easterly, "Electromagnetic fields and public health," Environmental Health Perspectives, Vol. 75, pp. 159-171, 1987. doi:10.1289/ehp.8775159

[7] Z. Gizatullin, and M. Shkinderov, "Research of noise immunity of computing equipment under exposure of electrostatic discharge," Paper presented at International Russian Automation Conference, Russia, 2019. doi:10.1109/runited statesutocon.2019.8867761

[8] S.M. Michaelson, "Influence of power frequency electric and magnetic fields on human health," Paper presented at Annals of the New York Academy of Sciences, United States, 1987. doi: 10.1111/j.1749-6632.1987.tb37646.x

[9] H. Sakurazawa, A. Iwasaki, T. Higashi, T. Nakayama, and Y. Kusaka, "Assessment of exposure to magnetic fields in occupational settings," Journal of Occupational Health, Vol. 45, pp. 104-110, 2003. doi: 10.1539/joh.45.104

[10] A.A. Wilcock, An Occupational Perspective of Health, Slack Incorporated, United States, 2006.

[11] H. Abbasi, M. Antunes, and J.I. Velasco, "Recent advances in carbon-based polymer nanocomposites for electromagnetic interference shielding," Progress in Materials Science Journal, Vol. 103, pp. 319-373 2019. doi: 10.1016/j.pmatsci.2019.02.003

[12] J. Yang, X. Liao, G. Wang, J. Chen, F. Guo, W. Tang, W. Wang, Z. Yan, and G. Li, "Gradient structure design of lightweight and flexible silicone rubber nano composite foam for efficient electromagnetic interference shielding," Chemical Engineering Journal, Vol. 390, pp. 1-32, 2020. doi: 10.1016/j.cej.2020.124589

[13] G. Rider, "A critique of the approach to controlling electrostatic risk in semiconductor production and identification of a potential risk from the use of equipotential bonding," AIMS Electronics and Electrical Engineering Journal, Vol. 3, pp. 397-414. 2019, doi: 10.3934/ElectrEng.2019.4.397 
[14] G. Ziegelberger, M. Repacholi, and A. McKinlay, "International commission on nonionizing radiation protection," Progress in Biophysics and Molecular Biology Journal, Vol. 92, pp. 1-3, 2006. doi: 10.1016/j.pbiomolbio.2006.02.022

[15] F.P. Grad, "The preamble of the constitution of the World Health Organization," Bulletin of the World Health Organization, Vol. 80, pp. 981-984, 2002.

[16] D.R. Lide, Handbook of Chemistry and Physics, CRC press, United States, 2016. 